\title{
The Structure of Mesoxylon Sutcliffii (Scott).
}

\author{
BY
}

\author{
ARTHUR J. MA.SLEN, F.L.S., F.G.S. \\ Formerly Marshall Research Scholar at the Royal College of Science. Lecturer on Geology \\ at the South-Western Polytechnic, Chelsea.
}

With Plates XXXIII-XXXVI.

CONTENTS.

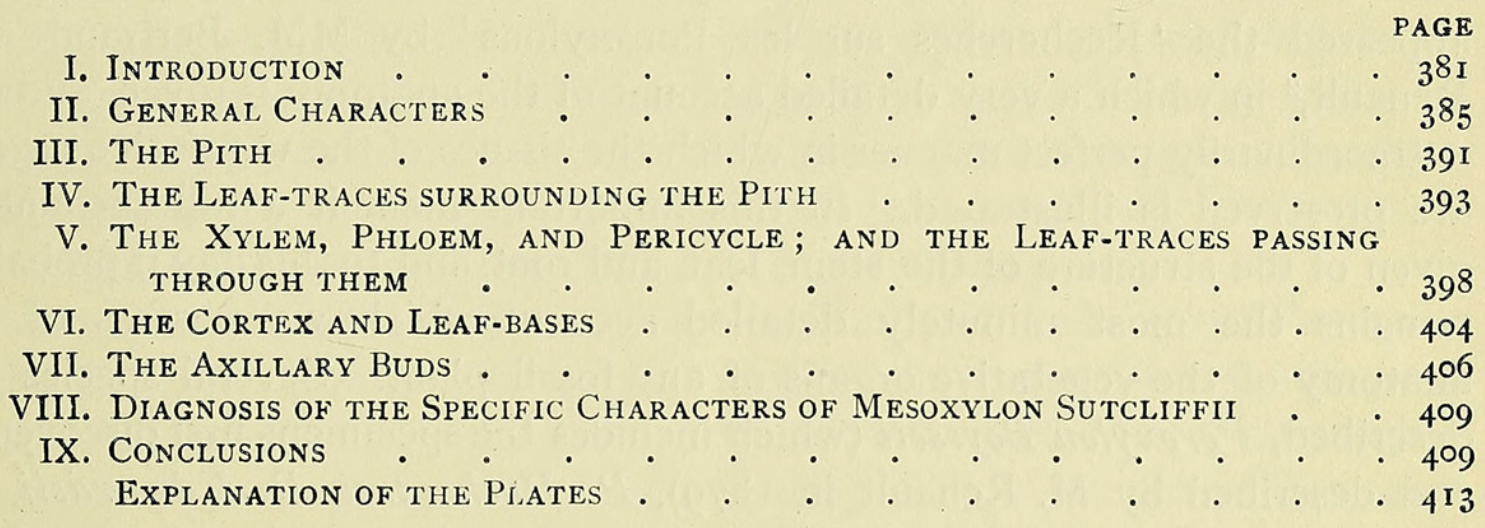

\section{INTRODUCTION.}

TAST year Dr. D. H. Scott, F.R.S., and I published a preliminary note: 'On Mesoxylon, a new genus of Cordaitales,' ${ }^{1}$ the object of which was to establish the new genus and to give brief diagnoses of the five species which had been recognized in preparations obtained from the calcareous nodules of the Lower Coal Measures of Lancashire.

Of the five species-Mesoxylon Sutcliffii, $M$.poroxyloides, $M$. multirame, $M$. Lomaxii, and $M$. platypodium-one form, $M$. Sutcliffi, had been already shortly described by Dr. D. H. Scott under the name Poroxylon Sutcliffii, with the qualification that 'though the plant is certainly related to the French Poroxylons, its place in the same genus must be regarded as provisional, until the investigations now in progress are completed.' In the same work some of the other species of Mesoxylon were referred to under Cordaites. ${ }^{3}$

1 Annals of Botany, vol. xxiv, I910, p. 236.

2 Studies in Fossil Botany, 2nd Edition, I909, p. 5 II, Fig. 184 .

${ }^{3}$ loc. cit., pp. 526, $55^{1}, 65^{\text {I. }}$. 
The object of the present paper is to give a full account of the structure of the stem and part of the leaves of Mesoxylon Sutcliffi, the only portions of the plant which are at present known, and to discuss the probable affinities of this form. The generic name Mesoxylon has been chosen to express the intermediate position of the genus between Poroxylon and Cordaites, and its special interest lies in the fact that the different species now known appear to almost completely bridge the gap, so far as the anatomy of the stem is concerned, between the Poroxyleae and the Cordaiteae, and thus form valuable links in the chain of forms connecting the Pteridosperms and Cycadofilices, with which Poroxylon and Mesoxylon have much in common, with the more typically Gymnospermous family of the Cordaiteae.

The family Poroxyleae was founded on specimens which were originally discovered in the Permo-Carboniferous deposits of Grand'Croix and Autun, and which were first described by M. Renault in $1879 .^{1}$ In 1886 appeared the 'Recherches sur les Poroxylons' by MM. Bertrand and Renault, ${ }^{2}$ in which a very detailed account of the anatomy is given, and the extraordinarily perfect manner in which the tissues of the vegetative organs are preserved is illustrated. In this important memoir a full account is given of the structure of the stem, leaf, and root, and to this day it probably remains the most minutely detailed account which we possess of the anatomy of the vegetative organs of any fossil plant. Several species are described, Poroxylon Boysseti (which includes the specimens first discovered, and described by M. Renault in I 879), P. Duchartrei, P. Edwardsii, $P$. Stephanense, \&c., of which $P$. Edwardsii and $P$. Boysseti are the two best known French forms.

The most important characters of the stem of Poroxylon are briefly as follows. The comparatively slender stems, less than $2 \mathrm{~cm}$. in diameter, bore relatively large simple leaves arranged in a spiral manner and separated by rather long internodes, which in the middle region of strongly developed branches attained a length of 2 or $3 \mathrm{~cm}$. The leaves themselves were simple, broad, and thick, and the lamina was traversed by numerous parallel veins. In the axils of many of the leaves the stem bore axillary branches. In structure the stem presents a fairly large continuous pith surrounded by a distinct ring of collateral leaf-trace bundles, and the development of the primary xylem of these bundles is described as being entirely centripetal. Each leaf-trace lying on the margin of the pith consists of two bundles which remain distinct for some distance below their entry into the interior of the stele, finally, however, fusing together, and, after running down through

1 B. Renault, (a) Sur un nouveau genre de tiges silicifiées de l'époque houillère. Comptes rendus de l'Académie des Sciences, t. lxxxviii, Séance du 6 janvier i879. (b) Structure comparée de quelques tiges de la Flore carbonifère. Paris, 1879, pp. 270-8. Nouvelles Archives du Muséum, ii, $2^{\mathrm{e}}$ série.

2 Bertrand and Renault, Archives Bot. du Nord de la France, I 886, pp. 243-389. 
thirteen internodes, joining the trace of a leaf vertically below. The continuous zone of centrifugal secondary wood is composed of rather large pitted elements separated by narrow medullary rays. The secondary phloem is excellently preserved in some forms, and in $P$. Edwardsii it consists, between the medullary rays, of alternate tangential bands of largecelled parenchyma and of sieve tubes with numerous compound sieve plates on their radial walls. The cortex is parenchymatous and contains in its outer part a strengthening system of hypodermal strands of sclerenchyma of the ordinary Dictyoxylon type, which is so commonly found in the stems and petioles of Palaeozoic plants. Periderm formation commenced at an early stage, and in older stems in which the phellogen cut right down into the phloem the whole of the cortex was thrown off as bark. Each leaf received from the stem a single large bilobed bundle (i.e. a double leaf-trace) at the base of the petiole, and division of this did not take place until the bundles had entered the leaf.

Since the publication of Bertrand and Renault's memoir on Poroxylon in I 886, Renault has added to our knowledge of the genus, ${ }^{1}$ and has given an account of the phloem of $P$. Boysset $i$ which shows that the regular structure of the phloem of $P$. Edwardsii mentioned above does not hold for the genus as a whole, and so is only a specific character in Poroxylon. ${ }^{2}$

More recently still M. Grand'Eury has identified the leaves of Poroxylon in the form of carbonaceous impressions, and finds that they are of great size, reaching a length of as much as a metre, with a breadth of $0.15^{-0.20}$ metre, and gradually narrowing at the base into the petiole. ${ }^{3} \quad$ M. Grand'Eury also attributes the platyspermic seed known as Rhabdocarpus, Brongniart, to Poroxylon: ${ }^{4}$ the attribution is on the ground of association, but if it is confirmed the evidence of affinity between the Poroxyleae and the Cordaiteae, which has hitherto been based on a study of the vegetative structure, will be very considerably strengthened.

With regard to the affinity of Poroxylon MM. Bertrand and Renault regarded the form as related, on the one hand, to the Cordaiteae, and on the other to the Sigillarieae. The relation to the Lycopods was supported by the case of Sigillariopsis (probably a form of Sigillaria), which possesses double foliar bundles and occasionally pitted tracheides. Bertrand and Renault, however, also indicated some of the points of resemblance between Poroxylon, Lyginodendron, and Heterangium, in the twin leaf-traces and pitted tracheides. ${ }^{5}$ In their 'conclusions' they state that: 'Les Poroxylons sont donc voisins des Sigillariées, des Sigillariopsis, des Lyginodendrons et des Heterangium, mais comme les rapports de ces types fossiles avec nos

\footnotetext{
1 Renault, Bassin houiller et permien d'Autun et d'Épinac. Flore Fossile, I896, Étude des gîtes minéraux de la France.

2 loc. cit., p. 284 .

3 Sur les Rhabdocarpus, les graines et l'évolution des Cordaïtées. Comptes rendus, t. cxl, I905, p. 995 .

5 Sur les Poroxylons, loc. cit., pp. $243,378$.
} 
plantes actuelles ne sont pas connus, ce rapprochement ne fixe pas la place des Poroxylons dans la classification.'

In Renault's later work he sums up the affinities of Poroxylon and states that: 'Les Poroxylons sont un type fossile sans représentants dans la nature actuelle; ce sont des Phanérogames gymnospermes inférieures, plus voisines des Cryptogames vasculaires à structure radiée que nos Cycadées, mais supérieures aux Sigillaires, aux Sigillariopsis, aux Lyginodendron et aux Heterangium. Ils n'ont aucun rapport avec les Filicinées.' ${ }^{1}$ In the light of our present knowledge the affinity of Poroxylon with the gymnospermous Cordaiteae on the one hand, and with the pteridospermic Lyginodendreae on the other, and so with the Filicineae, appears to be indisputable, while that with Sillgiaria and Sigillariopsis is certainly much more remote.

Our very complete knowledge of the vegetative and reproductive organs of Cordaites is principally due to the classic researches of MM. Grand'Eury and Renault, ${ }^{2}$ an epitome of which is given in all the textbooks. ${ }^{3}$

The principal anatomical distinctions between the stem of Cordaites and that of Poroxylon are the usually discoid pith of Cordaites, that of Poroxylon being continuous; the denser, more coniferous, wood of Cordaites; the structure of the phloem in Cordaites, different from that of Poroxylon; the division of the double leaf-trace in the pericycle in Cordaites, whereas in Poroxylon division is deferred until the leaf has been reached; and the absence in Cordaites of centripetal wood in the stele, the leaf-traces only acquiring it on entering the leaf. As Renault states, the stem of Cordaites is 'absolutely deprived of centripetal wood'.4

As already mentioned, the species of the new genus Mesoxylon appear to completely bridge the gap between the Poroxyleae and Cordaiteae. They may be said to combine the anatomical habit of a Cordaites with the centripetal xylem of a Poroxylon.

Before passing to the detailed description of Mesoxylon Sutcliffi it will be well to repeat here the generic diagnosis of Mesoxylon given in our preliminary note.

Mesoxylon (Scott and Maslen. Annals of Botany, vol. xxiv, I9I0, p. 237).

Pith relatively large, discoid. ${ }^{5}$

Wood dense, with narrow, usually uniseriate medullary rays, and relatively small tracheides.

1 Renault, Bassin houiller et permien d'Autun, \&c., loc. cit., p. 292.

2 Grand'Eury, Flore carbonifère du Département de la Loire, I877. Renault, loc. cit., Structure comparée, \&c., I879; Bassin houiller et permien d'Autun, \&c., loc. cit., I896.

3 e. g. Scott, Studies, and Edition, pp. 5I8-54.

- Renault, Bassin houiller et permien d'Autun, \&c., loc. cit., p. $33^{2}$.

5 This point is not yet demonstrated in the case of $M$. platypodium in which the interior of the pith is not preserved (see Prel. Note, p. 239). 
Maslen.-The Structure of Mesoxylon Sutcliffii (Scott). 385

Leaf-traces double where they leave the pith, the two strands uniting at a lower level, but undergoing further subdivision in the pericycle and cortex before entering the leaf.

Centripetal xylem present in the stem, where it forms part of the leaf-traces at the margin of the pith, and throughout their course outwards into the leaves.

The tracheides of the leaf-traces, so far as observed, are spiral or scalariform, and in some species this is also the case in the inner part of the intermediate secondary wood.

Throughout the genus the wood is of the kind usual in Cordaitales, the bulk of the secondary tracheides having multiseriate bordered pits on the radial walls.

Outer cortex strengthened by a system of sclerenchymatous bands of the Dictyoxylon or Sparganum type.

\section{MESOXYLON SuTCLIFFII.}

(Poroxylon Sutcliffi, Scott, Studies in Fossil Botany, 2nd ed., I909, p. 5II, Fig. 184).

\section{General Characters.}

The general characters of the genus Mesoxylon have already been described (p. $3^{84}$ ); it is proposed now to give those of our most fully known species, Mesoxylon Sutcliffii. The specific name, in honour of the owner of the colliery at Shore (reopened on account of its richness in fossil remains, and whence all the species have been obtained), was originally suggested by Mr. J. Lomax, who sent out the sections under the name Cordaites Sutcliffi.

At present only the stem, the leaf-bases, and the lower part of the petiole are known, and this is the only species of Mesoxylon in which anything is known of any part of the leaf other than the adherent leaf-bases. The stem of Mesoxylon Sutcliffii as represented by the numerous series of sections which have been examined in the preparation of this paperbelonging to at least nine distinct specimens-shows remarkably little variation in size. All the specimens have been somewhat flattened by pressure, but the average diameter, including the leaf-bases, is about $3 \mathrm{~cm}$., with a variation of only about $0.2 \mathrm{~cm}$. around this size. The stem is somewhat larger than that of any of the other species of Mesoxylon described in our preliminary note, excepting $M$. Lomaxii, which is of considerably larger size, being about $5 \mathrm{~cm}$. in diameter. Several of these species were, however, described from single specimens, and the discovery of others will doubtless show that all the species vary considerably in size.

Comparing Mesoxylon Sutcliffii with the French forms of Poroxylon, 
it is seen that the stem of the English form is larger than that of Poroxylon, which had comparatively slender stems less than $2 \mathrm{~cm}$. in diameter.

The outer surface of the stem has a very irregular contour, well seen in the transverse sections (Pl. XXXIII, Fig. I), which is due to the numerous crowded leaf-bases which completely cover the surface of the stem. Usually sections of some six or seven adherent leaf-bases are shown in the transverse sections (Pl. XXXIII, Fig. I, l. b.), and evidently the leaves covered the surface of the stem in a close spiral. Crowding of the leaves occurs in several of our species of Mesoxylon ( $M$. Sutcliffi, $M$, poroxyloides, $M$. multirame), while in others ( $M$. Lomaxii, $M$. platypodium) the leaf-bases are more scattered, but in no other known form are the leaves so densely crowded as they are in $M$. Sutcliffii.

In the crowding of the leaves Mesoxylon Sutcliffii is in strong contrast to Poroxylon, in which the leaves were separated by long internodes, sometimes as much as 2 or $3 \mathrm{~cm}$. in length. On the other hand, in some forms of Cordaites the leaves appear to have been crowded on the stem, although in the species hitherto described there was probably always a free internodal surface between the leaf insertions, and the leaves were therefore less crowded than in Mesoxylon Sutcliffi.

The stem probably bore its leaves in seven or eight vertical rows, or orthostichies, but some difficulty has been experienced in determining the exact phyllotaxis of $M$. Sutcliffi, owing partly to the flattening by pressure of most of the specimens, and partly also to the more or less patchy preservation of the internal tissues, including the leaf-traces, which is characteristic of the plants preserved, as these are, in the roof nodules. Pl. XXXIII, Fig. I, shows a transverse section of a stem which is only slightly flattened, and around it there are seven leaf-bases, which, counting also the petiole which would have been opposite to the bud shown on the top of the photograph, would indicate eight orthostichies. The angular divergence between two successive leaf-traces (P1. XXXIII, Fig. I, l.t., l.t.) appears to be about $140^{\circ}$, and the phyllotaxis is probably $\frac{8}{21}$, in which case the angular divergence would be $\mathrm{I} 37^{\circ}$. The phyllotaxis is thus of a higher order than that of Poroxylon, which was determined by MM. Renault and Bertrand to be $\frac{5}{13}$.

Although the leaves of Mesoxylon Sutcliffii are at present known only by their adherent bases and by a small portion of the petiole (P1. XXXV, Fig. I8), these show that they were probably broad strap-shaped leaves essentially similar to those of Cordaites (indeed some of the familiar impressions of Cordaitean leaves in the English Coal Measures may really belong to Mesoxylon), and of Poroxylon, the leaves of which have recently been identified by M. Grand'Eury in the form of impressions (see p. 383 ). That the leaves of Mesoxylon Sutcliffii were deciduous appears to be shown by the presence of a well-marked meristematic layer at their base (Pl. XXXIV, Fig. $13, a$ ). 
Passing to the internal structure of Mesoxylon Sutcliffi, we find that it presents, of course, all the general characters of the genus which have been already briefly described (p. 384). The stem is characterized by the possession of a relatively large pith (Pl. XXXIII, Fig. I), which in our specimens averages about $1.4 \mathrm{~cm}$. in diameter, or nearly one-half of that of the stem as a whole, including the bases of the leaves.

In the relative dimensions of the pith $M$. Sutcliffii resembles Cordaites and differs from Poroxylon, in which the pith is actually and relatively considerably smaller.

Transverse sections (P1. XXXIII, Fig. I) show that the pith presents a well-marked division into two regions: an outer one, p.p., consisting of a narrow continuous zone of parenchymatous cells, many of which possess dark contents, and a much larger central region, c.p., in which the medulla has a disorganized appearance. Longitudinal sections, however, show that the inner pith has a marked discoid structure (P1. XXXIII, Fig. 2, c.p.) somewhat resembling the well-known discoid pith found in most species of Cordaites.

The discoid pith is an important character which is probably common to all our species of Mesoxylon ${ }^{1}$ and to most forms of Cordaites, and it is one of the characters in which the new genus differs from Poroxylon, in which the pith is throughout a continuous mass of parenchymatous cells. Surrounding the pith, and in contact with the zone of secondary wood, are a considerable number of 'bundles' arranged very distinctly in pairs (P1. XXXIII, Fig. I, l.t., l.t., Figs. 3, 4). All these bundles represent the downward prolongation of the traces which have come in from the leaves, and which are also frequently seen traversing the cortex, pericycle, phloem, and secondary wood on their way to the inner part of the stele. In the transverse section from which Pl. XXXIII, Fig. I, has been made, twelve or more of these leaf-traces can be seen traversing various regions of the stem, and some of these are visible in the photograph at l.t., l.t., l'.t'., $l^{\prime} . t^{\prime}$., \&c. The great number of these traces is correlated with the complex phyllotaxis and crowding of the leaves in this species.

Each leaf-trace, as it lies on the margin of the pith, usually consists of two distinct bundles which are widely separated in the upper part of its course, and gradually approximate and ultimately fuse laterally into one bundle as the trace is followed down the stem (compare Pl. XXXIII, Figs. 3, 4, 5, which show a perimedullary leaf-trace at successively lower levels).

Each leaf-trace bundle consists distinctly of two portions, an outer part consisting of centrifugally-developed wood, and an inner part composed of centripetal xylem. These two portions are clearly shown on

1 This point is not yet demonstrated in the case of $M$. platypodium in which the inner pith is not preserved in our specimens. 
Pl. XXXIII, Figs. 3 and 4. The centrifugal wood, s.b., which constitutes by far the larger part of the bundles, consists of rows of radially arranged spiral or scalariform tracheides (Pl. XXXV, Fig. I4) which pass outwards, at the external limit of the bundle, by intermediate forms, into the ordinary pitted tracheides which form the continuous zone of secondary wood. The centripetal primary xylem (Pl. XXXIII, Figs. 3, 4, p.b.) of a trace bundle is much smaller in amount than the centrifugal wood, and consists of non-radially arranged elements, with spiral and scalariform thickenings, forming an arc. As far as we have been able to determine, the development of the inner arc of wood in Mesoxylon Sutcliffii was entirely in the centripetal direction, for we have been unable to demonstrate the presence of any centrifugal primary xylem elements, although it is possible that such may exist (see p. 393).

In the possession of paired leaf-trace bundles at the margin of the pith, Mesoxylon Sutcliffi agrees with the other species of Mesoxylon briefly described in our preliminary note, although there is much difference in the five species in the rapidity of convergence of the twin-bundles after their entry into the inner part of the stele. Twin leaf-trace bundles are also a feature of Poroxylon, and here, as in Mesoxylon, the two strands of a trace remain distinct for a considerable distance down the stem. Another Carboniferous plant in which the leaf-traces are given off in pairs from the margin of the pith is Dadoxylon Spenceri, ${ }^{1}$ a form which may prove to be closely related to Mesoxylon, and the same thing is shown in the living Ginkgo, ${ }^{2}$ relatives of which probably existed as far back as the Carboniferous Period.

Surrounding the pith and the leaf-trace bundles in all the specimens occurs a zone of secondary wood which has a thickness in Mesoxylon Sutcliffii of about $0.3 \mathrm{~cm}$. (Pl. XXXIII, Fig. I, s.x.). As is commonly the case in fossil plants which are preserved in the roof nodules, the preservation is somewhat patchy, and in all the specimens of $M$. Sutcliffi this is especially the case in the secondary xylem zone, the middle portion of which is often entirely destroyed (see Pl. XXXIII, Fig. I, s.).

The secondary xylem consists entirely of radially-arranged tracheides of small size (usually about $0.025 \mathrm{~mm}$. in diameter) and narrow uniseriate medullary rays, usually from $\mathrm{I}-6$ cells in height. With the exception of those which form part of the leaf-trace bundles, nearly all the secondary tracheides possess rows of bordered pits on their radial walls. The appearance of the tracheides in radial section is shown on Pl. XXXV, Fig. I5, and in tangential section on Pl. XXXV, Fig. I6. The wood is thus of the dense type with (usually) uniseriate rays and relatively narrow pitted tracheides which is common to all the species of Mesoxylon, and which is

1 Scott, Primary Structure of certain Palaeozoic Stems, \&c. Trans. Roy. Soc. Edinburgh, vol. xl, pt. ii, 1902.

2 Seward and Gowan, Ann. Bot., vol. xiv, 1900. 
known to be characteristic of Cordaites and of those specimens of wood which have been described under the names of Dadoxylon and Araucarioxylon, some of which have been identified as belonging to the Cordaiteae. Moreover, the secondary wood of Mesoxylon is practically indistinguishable from that of a Conifer of the family Araucarieae. Pairs of leaf-trace bundles are sometimes seen passing out through the zone of secondary wood, although, owing to the patchy preservation of this tissue and to the nearly horizontal course taken by the bundles, they are not as commonly met with in the transverse sections as might have been expected.

Outside the secondary xylem a cambium occurs, and the stem thus had secondary growth in thickness of a normal character.

The cambium is followed by a continuous zone of phloem, which is shown on Pl. XXXIII, Fig. 7 , p., and Pl. XXXV, Fig. I $7, p$. The secondary phloem has a thickness of about $0.6-0.8 \mathrm{~mm}$., and consists of elements arranged in radial rows corresponding to those of the secondary wood separated by narrow medullary rays. In addition to long empty-looking cells (? sieve tubes) the phloem includes many long tubular elements containing dark contents. The structure of the phloem is much more like that of Cordaites than that of Poroxylon Edwardsii (see p. $3^{8} 3$ ).

Surrounding the phloem there is a fairly thick band of tissue which may be interpreted as the pericycle (see Pl. XXXIII, Fig. 7, pe., and Pl. XXXV, Fig. I 7,pe.), although it does not appear to be sharply marked off from the cortical tissue outside. Longitudinal sections show that this zone consists mainly of rather large short parenchymatous cells, most of which possess brown contents (Pl. XXXIV, Fig. I3, pe.), and which are essentially similar to those which form the greater part of the outer persistent pith.

The paired leaf-trace bundles, after their escape from the zone of secondary xylem (which they traverse in a nearly horizontal direction), ascend steeply (almost vertically) through the phloem and pericycle, so that in transverse sections of the stem the bundles are cut across nearly transversely, as is shown on Pl. XXXIV, Figs. 8 and 9. When once free from the xylem cylinder the leaf-trace bundles possess a distinct collateral structure with external phloem, and this collateral structure is preserved as far out as the bundles can be traced into the leaves.

On reaching the phloem and pericycle the leaf-trace bundles, which still possess centrifugal and centripetal wood, experience a marked tangential dilatation which is preparatory to the division of each bundle into two which takes place in the inner part of the pericycle (Pl. XXXIV, Fig. 8). A similar division to that described in Mesoxylon Sutcliffi takes place in the other species of Mesoxylon; in one species, however-M. platypodiumeach of the bundles had already divided, as regards its primary xylem, even before leaving the wood. ${ }^{1}$

1 Scott and Maslen, Mesoxylon. Preliminary Note. Ann. Bot., vol. xxiv, p. 239.

D d 


\section{Maslen.-The Structure of Mesoxylon Sutcliffii (Scott).}

A similar division of each leaf-trace bundle into two in the pericycle also takes place in many (or all ?) species of Cordaites, in which genus the leaf-trace is also a double one, while in Poroxylon, which agrees with Mesoxylon and differs from Cordaites in the possession of paired leaf-trace bundles at the margin of the pith, division of the bundles did not take place until the trace had entered the leaf.

The primary cortex of Mesoxylon Sutcliffii, as well as the leaf-bases by which the stem is covered, consists of parenchyma traversed in the outer part by a system of strengthening bands of the Dictyoxylon or Sparganum type similar to that found in so many other Palaeozoic plants (see Pl. XXXIII, Fig. I, d.). Secondary cortical tissues were formed in abundance, and a number of successive periderms are seen (Pl. XXXIV, Fig. 9, $p^{\prime}$., $p^{\prime}$., and Fig. IO, $p^{\prime}$.), which eventually cut right down to the pericycle, or even deeper still. The leaf-trace bundles which, as we have seen, divide in passing through the pericycle, continue to do so in traversing the cortex before entering the leaf (see Pl. XXXIV, Figs. 9 and 10). In some sections as many as eight separate bundles belonging to one trace are seen in the cortex near the junction of the cortex and an adherent leaf-base, and ten or more in the leaf-base itself while it is still adherent to the stem.

In Mesoxylon Sutcliffi the lower part of the free petiole is sometimes preserved, and one of these is shown on Pl. XXXV, Fig. I8; it is of flattened form, and shows ten bundles. As many as sixteen bundles are sometimes found in the petiole within a very short distance of its insertion, showing that division of the trace bundles continues to take place after they enter the leaf.

Throughout their course, as far as they can be traced in our specimens, the leaf-trace bundles retain their collateral structure, and in the petiole the inner wood of the bundles appears to attain a more distinctly mesarch structure. In the possession of mesarch collateral leaf bundles our plant agrees with some species of Cordaites (see p. 406) as well as with modern Cycads.

An interesting feature in the morphology of Mesoxylon Suicliffii is the abundance of axillary buds; indeed, a bud appears to occur in the axil of every leaf in our specimens. Axillary branching is a feature of several of the species of Mesoxylon ( $M$. multirame, $M$. platypodium, see preliminary note), as well as of Poroxylon. In Mesoxylon Sutcliffi, owing to the crowding of the leaves on the stem, axillary buds are more frequently seen than in any other known Carboniferous plant; a single transverse section such as that shown on P1. XXXIII, Fig. I, frequently shows two or three buds, $a . b$., $a . b$, and in addition to these, other bud-steles, a.b.s., embedded in the cortex, which pass out to buds which arise in the axils of leaves at a higher level. P1. XXXIV, Fig. Io, shows one of these axillary bud-steles in the cortex with its subtending leaf-base and a row of six leaf-trace bundles. In 


\section{Maslen.-The Siructure of Mesoxylon Sutcliffii (Scott).}

several of the sections two distinct bud-steles corresponding to a single leaf are seen embedded in the pericycle (see P1. XXXIV, Fig. 12): each of these appears to be a complete closed stele, and they doubtless result from the division of the single larger stele which is seen in slides cut from the same specimen at a somewhat higher level.

A transverse section of an axillary bud is shown on Pl. XXXVI, Fig. 20, and it will be seen that the stele possesses a relatively large pith surrounded by five or six distinct bundles separated by broad medullary rays. Fig. 20 also shows some of the closely packed leaves of the bud, while on Pl. XXXVI, Fig. 2I, a better preserved bud-scale is shown with two very small bundles, $b$., $b$, close together near the centre of the leaf.

In all the sections of Mesoxylon Sutcliffii which have been examined, the buds appear to be in almost exactly the same stage in development; in no case has a bud grown out into a distinct branch. Presumably they were resting buds of some kind, though whether vegetative or reproductive has not been determined.

Having described the general structure of Mesoxylon Sutcliffi, we proceed now to a more detailed description of the various tissues, taking them in order from within outwards.

\section{The Pith.}

The stem of Mesoxylon Sutcliffii possesses a relatively very large pith, as shown on Pl. XXXIII, Fig. I, the average diameter in our specimens being about $\mathrm{I} \cdot 4 \mathrm{~cm}$., or nearly one-half that of the stem as a whole, including the leaf-bases. The large size of the pith appears to be characteristic of the new genus as a whole, since in four out of the five species yet discovered it has a diameter nearly half of that of the whole stem. There is a wellmarked division of the pith into two regions: an outer narrow continuous zone of parenchymatous cells, p.p., and a much larger central region, c.p., which has a discoid structure as seen in longitudinal sections (see Pl. XXXIII, Fig. 2, c.p.) resembling the well-known discoid pith found in most species of Cordaites. The discoid structure was no doubt due to the fact that the more central part of the pith was not able to follow the growth of the stem in length, and consequently split across at short intervals, leaving gaps between the persistent diaphragms; at the outer edge, next the wood, the medullary tissue remained continuous.

The central discoid pith has a diameter of about I. I cm., that of the whole pith being about $\mathrm{I} \cdot 4 \mathrm{~cm}$. In most of the sections the inner pith has contracted away from the persistent outer zone with which it was originally continuous. Thus, in the transverse section shown on Pl. XXXIII, Fig. I, the outer edge of the discoid pith, c.p., has contracted away from the outer pith, p.p., at the sides of the section, leaving a space between, while at the top and bottom the two tissues are still continuous. Again, in the longitudinal

$$
\text { D d } 2
$$


section shown on P1. XXXIII, Fig. 2, a wide space occurs between the two regions of the pith on the left, while on the right they are perfectly continuous.

The central pith, as shown on P1. XXXIII, Fig. 2, c.p., consists of somewhat irregular, but on the whole transversely arranged, diaphragms with intervening spaces. Between the horizontal plates of tissue there are numerous fine connecting strands, and the discoid structure is clearly the result of longitudinal tension and contraction during the growth of the plant. In the transverse sections (Pl. XXXIII, Fig. I) the discoid pith presents quite an irregular appearance, owing to the fact that the transverse diaphragms are rarely strictly horizontal (see Fig. 2) in the somewhat contracted condition in which they are preserved. In transverse sections, the cells of which the diaphragms are composed appear nearly round in form, with a diameter in the central region of $0.15 \mathrm{~mm}$. to $0.20 \mathrm{~mm}$. In the longitudinal sections the cells appear somewhat flattened, and are seen to be arranged in more or less horizontal rows. All the cells have a somewhat disorganized appearance. The cells in the central parts of the diaphragms are larger than any of those in the outer persistent pith.

The outer continuous zone of the pith consists entirely of more or less isodiametric parenchymatous cells, many of which possess dark brown contents. This zone is well shown in transverse section on Pl. XXXIII, Figs. 3 and 4, and in longitudinal section on Pl. XXXIII, Fig. 6. As is shown in the latter figure, the cells of the outer pith are arranged in vertical rows when seen in longitudinal sections. The cells frequently present the appearance of not being in contact, an appearance which is probably due to contraction of the contents prior to fossilization. The sections (Pl. XXXIII, Figs. $3,4,5$ ) usually show some differentiation of the cells of the outer pith in concentric regions or zones, which pass, however, gradually into one another. Immediately adjacent to the outer boundary of the discoid pith, and passing gradually into it, occurs a zone of empty-looking cells with thin walls (Pl. XXXIII, Fig. 3, $p^{\prime}$., Fig. $4, p^{\prime}$., Fig. $6, p^{\prime}$.) ; next follows a zone in which the cells are usually filled with brown contents (P1. XXXIII, Fig. $3, p^{\prime \prime}$., Fig. $\left.6, p^{\prime \prime}.\right)$; outside this zone of cells with dark contents a number of smaller empty cells are sometimes seen next to the xylem (P1. XXXIII, Fig. $4, p^{\prime \prime \prime \prime}$.), and these in longitudinal sections are found to be vertically elongated cells with rather thick walls, and quite different in shape from the somewhat tabular (short vertically) dark cells within (see P1. XXXIII, Fig. $6, p^{\prime \prime}$.)

The zone of contents-filled cells itself usually consists of elements of two kinds, some of the cells containing pale-brown contents, while the others are filled with very dark-brown, sometimes almost black, material. The very dark cells frequently occur as a kind of subzone outside the paler-coloured ones (Pl. XXXIII, Figs. 4 and $5, p^{\prime \prime \prime}$.). The subzone of cells with very dark contents is not always clearly differentiated in the transverse sections, and 
when present it is not equally developed all round the periphery of the pith, being usually absent, or nearly so, opposite to the outgoing leaf-traces, especially where the two bundles are widely separated preparatory to their exit as on P1. XXXIII, Fig. 3. Where, as shown on Pl. XXXIII, Figs. 4 and 5 , the bundles of the trace are more closely approximated (i.e. when the trace is cut through at some distance below its entrance into the central part of the stele), the zone of cells with very dark contents, $p^{\prime \prime \prime}$., again appears. Somewhat similar cells with dark contents ('secretory sacs') occur in the parenchymatous tissues of Pitys and Cordaites.

\section{The Leaf-Traces surrounding the Pith.}

As already briefly described, a considerable number of leaf-trace bundles occur around the pith in contact with the zone of secondary wood. These bundles occur in pairs, a pair ultimately passing out to each leaf. If a leaf-trace is cut through soon after its entry into the interior of the stele the twin-bundles are widely separated (P1. XXXIII, Fig. 3), but when traced down through the stem the two bundles gradually approximate to one another (Pl. XXXIII, Fig. 4), and fuse laterally into one bundle (P1. XXXIII, Fig. 5), and, finally, when traced still lower, the identity of this as a distinct bundle is lost.

Each leaf-trace bundle on the margin of the pith consists of both centrifugally and centripetally developed xylem, the former constituting by far the greater part of the bundle and passing gradually outwards into the tracheides which form the continuous ring of secondary wood.

The centripetal primary xylem of a trace bundle is much smaller in amount than the centrifugal wood, and consists of a number of non-radially arranged elements with spiral and scalariform thickenings, forming an arc, convex inwards, abutting at its ends on the rows of centrifugally developed tracheides of the bundle (P1. XXXIII, Fig. 3, p.b.). Between the centrifugal outer xylem and the primary centripetal xylem there is a small mass of tissue consisting of delicate parenchymatous cells (PI. XXXIII, Figs. 3 and $4, p x$.). This doubtless consists of conjunctive parenchyma accompanying the protoxylem elements, and it thus serves to mark the position of the protoxylem. Each bundle is surrounded laterally and internally by an empty space, which is shown on P1. XXXIII, Figs. 3 and $4, s$; it represents the position of a very delicate tissue, which is rarely preserved even in part. This conjunctive tissue accompanies the bundles out through the wood, and is preserved around the bundles in the phloem and pericycle (Pl. XXXIV, Fig. 8, b.).

As far as it has been possible to determine, the development of the primary wood in the stem of Mesoxylon Sutcliffi was entirely in the centripetal direction. As can be seen on Pl. XXXIII, Figs. 3 and 4 , the smallest elements of the inner mass of xylem, p.b., occur at or near its outer limit 


\section{Maslen.-The Structure of Mesoxylon Sutcliffii (Scott).}

and in contact with the conjunctive tissue, while the elements outside this are radially arranged and presumably partly or entirely of secondary origin. Unfortunately the longitudinal sections do not suffice to decide the question as to the existence of some centrifugally developed primary xylem. An analogous case is found in Poroxylon, where, according to the observations of MM. Bertrand and Renault, there is no centrifugal primary xylem, but in this case also this is a point which might repay further investigation. ${ }^{1}$ In the Cordaiteae of the type described by Renault, to which Mesoxylon is evidently in many respects closely related, the elements of the wood are radially arranged throughout, so that in transverse sections there is no distinction between primary and secondary xylem. In the radial sections of Cordaites, however, we find a marked change, from the pith outwards, in the structure of the walls of the tracheides. ${ }^{2}$ The narrow spiral elements of the protoxylem are succeeded by wider spiral tracheides, and these again by scalariform elements. It is not until many rows have been passed that we come to the pitted tracheides, which form the bulk of the wood. The transitional region between primary and secondary xylem in Cordaites is thus an extensive one, and it is impossible either in transverse or in longitudinal sections to draw a sharp line between the two tissues. The protoxylem elements in Cordaites are localized in groups, often projecting somewhat into the pith, and marking the position of the primary bundles. Comparing the structure of Cordaites with that of Mesoxylon Sutcliffi, it is seen that the radially-arranged xylem of a leaf-trace bundle of $M$. Sutcliffii agrees in a general way with the inner wood of Cordaites in consisting of spiral and scalariform tracheides, passing outwards, at the limit of the bundle, and by intermediate forms, into the pitted tracheides which form the bulk of the wood, but it has been impossible to identify any definite protoxylem elements in the radially-arranged portion of the bundle, either by their smaller size in transverse section or by their special thickening in longitudinal ones. In Mesoxylon Sutcliffi the smallest xylem elements always occur at the outer limit of the inner, centripetal wood. On analogy, then, with Cordaites, we may perhaps regard the radiallyarranged xylem of the leaf-trace bundles of Mesoxylon Sutcliffii as representing part of the primary wood and also the transition region between the primary and secondary xylem. Passing to the mass of irregularly (i. e. nonradially) arranged tracheides which constitutes the inner wood of the leaftrace bundles, it is found, as already mentioned, that the smallest elements occur on its outer side, so that the structure of this part of the wood is apparently exarch, as is the case in Poroxylon, according to MM. Bertrand and Renault.

1 Scott, Studies, 2nd Ed., p. 505 .

2 See figure of Cordaites (Araucarioxylon) Brandlingii, in Scott, Studies, 2nd Ed., Fig. 190, p. 528 . 


\section{Maslen.-The Structure of Mesoxylon Sutcliffii (Scott). 395}

In connexion with the subject of the inner wood of the leaf-traces of Mesoxylon Sutcliffi, mention may also be made of Pitys antiqua and Dadoxylon Spenceri, two plants which are probably closely related to the Cordaiteae, and of Calamopitys fascicularis, which probably also belongs to the same plexus of intermediate forms between the Pteridosperms on the one hand and the Cordaiteae on the other. Pitys antiqua ${ }^{1}$ is a tree found in the Lower Carboniferous of Southern Scotland, and its wood agrees with that of the Cordaiteae and Mesoxylon, except for the greater width of the medullary rays. Around the large pith as many as forty or fifty xylem strands are found, most of which are embedded in the pith at some little distance from the inner edge of the woody zone, with which they only come into contact when about to make their exit as leaf-traces. Here the leaftrace as a whole consists of but one bundle, and this appears to correspond with the inner wood only of the trace bundle of Mesoxylon Sutcliffii, and from this it differs in being definitely mesarch in structure and in being usually separated from the main zone of wood. In Dadoxylon Spenceri, ${ }^{2}$ a Coal-Measure form, the leaf-traces are given off in pairs as in Mesoxylon, and here they are also in contact with the woody zone. Traced downwards, the strands of each pair fuse as in Mesoxylon; they are mesarch in the upper part of their course, but at a lower level the centripetal wood appears to die out, a change which also occurs, as we shall see, in Mesoxylon Sutcliffii. Dadoxylon Spenceri possesses dense secondary wood with narrow tracheides and uniseriate medullary rays, i. e. wood of the Cordaitean type, and in all probability close relationship will ultimately be found to exist between this form and the genus Mesoxylon.

In the stem of Calamopitys fascicularis, ${ }^{3}$ again, which stands probably nearer to the Pteridosperms than Pitys and Dadoxylon, we find the pith surrounded by a circle of primary xylem strands, eight or nine in number. Each of the traces consists of a single very large bundle in which no radially arranged elements are found, and in which the structure is distinctly mesarch. In the large strands near their exit the protoxylem is central; lower down, as the strand diminishes in diameter, the centripetal wood becomes relatively reduced in amount.

Returning to Mesoxylon Sutcliffii, there may be just a suggestion in some of our slides that the inner wood is not entirely centripetal in its development, i.e. that there may be a few non-radially arranged elements outside the mass of thin-walled tissue which marks the position of the protoxylem. Although it has been impossible to prove that this is the case, the analogy of Dadoxylon Spenceri and the other forms just described appears to make it not improbable that the inner wood of the perimedullary

1 Scott, Primary Structure of certain Paleozoic Stems, \&c. Trans. Roy. Soc. Edinburgh, vol. xl, pt. ii, I902.

${ }^{2}$ Scott, loc. cit., p. 357 .

Scott, loc. cit., p. 332 . 
traces in Mesoxylon Sutcliffi is mesarch also. As the whole of the elements of the trace, centrifugal as well as centripetal, consists of tracheides with similar spiral and scalariform thickenings, the longitudinal section affords little help in determining this point.

Tracing the twin-bundles of a leaf-trace of Mesoxylon Sutcliffii downwards from the level at which they have just reached the margin of the pith, after coming in from a leaf, the following changes are seen to take place.

Pl. XXXIII, Fig. 3, shows a leaf-trace shortly after it has entered from a leaf, magnified about 40 diameters. The two bundles of the trace are, at this level, separated by tissue, s.x., about equal in width to that of one of the bundles, and the distance between the bundles (measured from the centre of each) is about $0.9 \mathrm{~mm}$. The intermediate tissue consists partly of ordinary secondary xylem elements, s.x., arranged in radial rows, and partly of larger cells which belong to the pith.

There is considerable difference between the five species of Mesoxylon in the distance between the bundles of a trace, and in the rapidity with which they fuse together when followed down the stem: ${ }^{1}$ in $M$. Lomaxii the twin-bundles fuse immediately on reaching the pith, while $M$. platypodium is characterized by the extreme separation (as much as $2 \mathrm{~mm}$.) of the bundles. Mesoxylon Sutcliffii occupies an intermediate position in this respect, the separation being about $0.9 \mathrm{~mm}$.

At this level (P1. XXXIII, Fig. 3) the centripetal wood, p.b., is quite well developed, and the arc-like form is more pronounced than in sections of the trace at lower levels. Each bundle is partly surrounded by the space, $s$., above mentioned.

On P1. XXXIII, Fig. 4, a leaf-trace is shown after it has passed down through, probably, several internodes. Here the bundles have become approximated to one another, and the distance between the two bundles is now about $0.55 \mathrm{~mm}$. Otherwise there is but little difference between the trace at the two levels represented in Figs. 3 and 4, excepting that at the lower level the centripetal wood is perhaps slightly smaller in amount, and its arc-like form is less evident.

Pl. XXXIII, Fig. 5, shows a leaf-trace at a still lower level. Here the two original bundles have fused laterally into one broad bundle, although the two masses of centripetal xylem, $p . b$., are still distinct. The distance between the centres of the individual bundles is now only $0.4 \mathrm{~mm}$. The amount of centripetal wood is distinctly less and the arc form is lost. Examination of the traces at even lower levels shows that the previously distinct inner wood of the two bundles fuses into one straight line and finally disappears altogether, leaving only the radially arranged centrifugal elements abutting on the pith, and these gradually lose their identity as distinct bundles altogether.

${ }^{1}$ Scott and Maslen, Preliminary Note, loc. cit. 


\section{Maslen.-The Structure of Mesoxylon Sutcliffii (Scott). 397}

On P1. XXXIII, Fig. 6, a longitudinal section passing through the two bundles of a leaf-trace at the margin of the pith is shown. The cells of the outer pith are shown at $p^{\prime \prime}$, and the inner part of the secondary xylemring at s.x. The latter consists mainly of closely packed, straight, pitted tracheides with narrow medullary rays shown at $a$, but on its inner margin, $b$, the tracheides are spiral or scalariform, and follow a more undulating course and have broader medullary rays : the latter part, in fact, presents a similar appearance to that of the centrifugal xylem of the leaf-traces described below. In this more or less tangential section (P1. XXXIII, Fig. 6) the leaftrace bundles, l.t., l.t., are seen in the outer part of the pith. In the upper part of the photograph (P1. XXXIII, Fig. 6) two distinct bundles are shown with medullary elements between them, while below they have fused into one broad bundle exactly as we have seen to take place from a study of the transverse sections.

The long straight course of the bundles is well seen in this slide, where the same two bundles can be traced for a distance of $0.6 \mathrm{~cm}$., and they are of course only intercepted by the plane of section for a short part of their course. The very slow convergence of the bundles of a trace is also well illustrated by this slide, since there is but little diminution in the distance between the two bundles in the distance $(0.6 \mathrm{~cm}$.) shown in the photograph.

The centrifugal tracheides of the bundles follow a somewhat undulating course, as is seen in the photograph (P1. XXXIII, Fig. 6, s.b.), and between them are relatively broad medullary rays. The appearance of this tissue in longitudinal sections is quite different from that of the secondary xylem zone with its closely packed, straight tracheides and narrow medullary rays. Some of the centrifugal xylem elements from one of the bundles shown on Pl. XXXIII, Fig. 6, are also shown on a larger scale on Pl. XXXV, Fig. 14. Here the thickening of the walls of the tracheides appears to be of the spiral kind, and between the tracheides the relatively broad medullary rays are shown. The scalariform centrifugal tracheides of the bundle pass gradually, by transitional forms, into the pitted tracheides which form the ring of secondary wood. In the centrifugal xylem of the bundle the spiral or scalariform tracheides are thickened on all sides, while in the ring of secondary xylem outside the bundles the pitting is confined to the radial walls, as is usually the case in secondary xylem elements. The centripetal wood of the bundles is shown on Pl. XXXIII, Fig. 6, p.b., cut obliquely as the plane of the section passes into the pith. It forms a denser kind of wood than the centrifugal xylem, as it consists entirely of spiral or scalariform tracheides. Between the centrifugal and centripetal wood the slide shows some traces of narrow elements with loose spiral thickening which doubtless belong to the protoxylem. The fact that all the tracheides of the leaf-trace in Mesoxylon Sutcliffii (as well as in the other species of the 


\section{Maslen.-The Structure of Mesoxylon Sutcliffii (Scott).}

genus) have spiral or scalariform thickening is a difference between this form and Poroxylon, in which not only are the centrifugal elements provided with vertical rows of bordered pits, but even in the arcs of primary (centripetal) wood the more internal part of each bundle consists of pitted elements passing outwards into scalariform ones and these into the spiral tracheides of the protoxylem, exactly as is the case in Lyginodendron and Heter. angium.

The sections show that not only does the centripetal xylem gradually diminish in quantity and finally die out altogether when the trace bundles are followed down the stem, but that the centrifugal wood also gradually decreases in amount. Owing to the difference in the nature of the tracheides of the centrifugal portion of a bundle and of the centrifugal secondary wood outside, it is easy to distinguish them in longitudinal sections.

\section{Tiie Xylem, Phloem, and Pericycle; and the Leaf- TRACES PASSING THROUGH THEM.}

Surrounding the pith and the leaf-trace bundles occurs the zone of secondary wood, having a thickness in Mesoxylon Sutcliffii of about $0.3 \mathrm{~cm}$. (Pl. XXXIII, Fig. I, s.x.). The patchy preservation of this tissue has already been mentioned (p. $3^{88}$ ), and it is illustrated by the sections shown on Pl. XXXIII, Figs. I and 2. As is shown in Fig. I the middle portion of the wood is often entirely destroyed, resulting in an irregular space, $s$., while the outer and inner portions may be excellently preserved. The same thing is shown in the radial longitudinal section seen in Fig. 2: the secondary wood, s.x., on the left of the section shows a middle empty space, while on the right nearly the whole of the xylem has been destroyed. Why the middle portion of the wood should be specially liable to destruction, while soft delicate tissues such as the phloem and pericycle are often well preserved, is not easy to determine.

The wood consists entirely of radially arranged tracheides of small size, and of narrow, generally uniseriate, medullary rays usually from $1-6$ cells in height (see Pl. XXXV, Fig. I6). Two or three vertical rows of bordered pits are usually seen in radial sections on the radial walls of each tracheide (Pl. XXXV, Fig. I5), while in tangential sections no pits are visible (Pl. XXXV, Fig. I6) since they are confined to the radial walls of the elements. The tracheides and narrow medullary rays of the secondary xylem are shown in transverse section on Pl. XXXIII, Fig. 7, s.x., and P1. XXXV, Fig. I7, s.x., \&c.

The similarity in structure of the secondary xylem of Mesoxylon and that of other Cordaitales has already been pointed out (see p. 388). Comparison of the secondary xylem of Mesoxylon Sutcliffi $i$ with that of Poroxylon shows that in the latter form the tracheides are much larger, and that, owing to this 
fact and to the greater thickness of the medullary rays, the wood of Poroxylon is of a softer, less compact type, comparable rather with that found in Lyginodendron and other Cycadofilices. Indeed, the dense character of the wood seems to afford a ready means of distinction between the Cordaiteae and the forms more closely related to them, such as Mesoxylon, and the more distant Poroxyleae, Cycadofilices and Pteridosperms, in which the secondary xylem is of a softer, more Cycadean type with larger tracheides and broader medullary rays.

The radially arranged wood which occurs immediately around the pith and between the perimedullary leaf-trace bundles (the 'intermediate secondary wood' of our preliminary note) presents a somewhat different appearance in transverse sections to that of the rest of the wood. In many places this wood doubtless represents the downward extension of the centrifugal portion of leaf-trace bundles which have nearly lost their individuality. In other places, however, where there is not the slightest trace of bundles, the innermost tracheides of the radial rows are smaller than those further out, while the number of radial rows is less and the width of the rays greater. In other words, the intermediate wood for a short distance in from the pith presents the less compact appearance which is characteristic of the outer wood of the traces.

Radial longitudinal sections show, however, that in some places there are only one or two scalariform, spiral or transitional elements between the ordinary tracheides with bordered pits and the cells of the pith. In other cases, where a greater thickness of such elements is shown, it is probable that the prolongation of a leaf-trace is cut through. In the more or less tangential section represented on P1. XXXIII, Fig. 6, spiral elements are shown at the inner limit of the secondary wood at $b$; it appears probable that this is really part of a leaf-trace: It thus appears that, with the possible exception of a very few elements on its inner edge, the whole of the secondary xylem-ring, apart from the leaf-traces, consists of pitted tracheides.

Pairs of leaf-trace bundles are sometimes seen in the transverse sections passing out through the secondary wood. When cut across in the inner part of the secondary xylem the bundles are cut nearly transversely, but when in the outer part they appear in obliquely longitudinal section, from which it is inferred that their course through the wood is at first highly inclined (i. e. nearly vertical), and then, having fairly entered the secondary wood, they curve rapidly (owing to the growth in thickness of this zone) and assume a more nearly horizontal direction. After leaving the wood the inclination again increases, and in the phloem and pericycle the bundles are cut nearly transversely. One of the longitudinal sections, ${ }^{1}$ a tangential one passing through the outer part of the secondary xylem, shows a pair of

\footnotetext{
1 Slide No. 2666 (S).
} 
leaf-trace bundles cut across nearly transversely, owing to their nearly horizontal course through the wood. Each bundle in traversing the wood has its centripetal wood directed upwards and projecting into a space, resembling somewhat the well-known rootlet bundles of a Stigmaria as seen in tangential sections of the wood. The space into which the centripetal wood projects clearly corresponds with that shown in the transverse sections around the bundles surrounding the pith (Pl. XXXIII, Figs. 3 and $4, s$.$) , and it was doubtless occupied by delicate conjunctive parenchyma.$ Between this space (as seen in the tangential section) and the secondary tracheides of the xylem-ring there is a tissue which is probably continuous with the outer pith.

The transverse sections appear to indicate that in many cases the two bundles of a trace may have emerged from the wood at slightly different levels, so that when one bundle was well out in the phloem and is cut nearly transversely, the other was still embedded in the wood, and so is cut through in a more or less longitudinal direction. Thus in the trace at the right of the photograph shown on P1. XXXIII, Fig. I, one of the bundles is seen to be fully out while the other has not yet escaped from the secondary xylem. Slight obliquity of the section together with the very rapid curving upwards of the bundles when they leave the xylem may perhaps be sufficient reason to account for this appearance.

The secondary xylem is followed by the cambium. This tissue, which is rarely preserved, is shown on Pl. XXXV, Fig. I7, c., and consists of thinwalled cells of tabular form, narrower in the radial direction than in the tangential one. Traversing the cambium are seen narrow medullary rays continuous with those of the secondary xylem.

Beyond the cambium occurs a continuous zone of secondary phloem having a width of about $0.6-0.8 \mathrm{~mm}$. when measured at some distance from an emerging leaf-trace, near to which the phloem is usually much disturbed. The phloem zone is shown in transverse section on Pl. XXXIII, Fig. $7, p$., P1. XXXV, Fig. $\mathrm{I} 7, p$., and in longitudinal section on P1. XXXIII, Fig. 2, $p$., and Pl. XXXIV, Fig. I3, $p$. It consists mainly or entirely of elements which are arranged in radial rows corresponding to those of the secondary wood and with similar narrow medullary rays. In addition to long thin-walled elements (? sieve tubes) the phloem contains many long tubular cells or vessels with dark contents. These latter elements appear to be of two kinds. Some present a characteristic square form in transverse sections and have very dark contents (Pl. XXXIII, Fig. $7, p^{\prime}$., and Pl. XXXV, Fig. $I 7, a)$, while in longitudinal sections they appear as very long straight tubes without apparent cross-walls. They may occur in any part of the secondary phloem, but are found more especially in the inner portion as seen on Pl. XXXIII, Fig. 7. They frequently occur in tangential rows as shown on P1. XXXV, Fig. I7. The other tubular elements with contents 
of the phloem have much paler contents and are more like the majority of the cells in the pericycle and the outer pith as seen in transverse sections. They are usually somewhat larger than the cells with darker contents, although smaller than the cells of the pericycle (see P1. XXXIII, Fig. $7, p^{\prime \prime}$., and Pl. XXXV, Fig. 17, b). These, too, appear in longitudinal sections as long tubes without obvious cross-walls, although they (or their contents) are broken across at irregular intervals.

Between the cells with contents, occur numerous long, narrow, thinwalled empty-looking cells (see Pl. XXXV, Fig. I 7, c), which may be of the nature of sieve tubes, although no actual sieve plates or sieve areas can be seen. Other thin-walled empty elements appear to have cross-walls at fairly close intervals, and these may perhaps be regarded as phloem parenchyma.

The medullary rays in the phloem are shown on Pl. XXXV, Fig. I7, $m . r$, in transverse section. They are not well shown in any of our radial sections of the phloem, but the cells appear to be narrow vertically and somewhat elongated radially.

At the outer limit of the phloem, or between that tissue and the pericycle, there sometimes occurs a more or less well-defined tissue consisting of thin-walled cells and cells with very dark contents. This tissue is shown on Pl. XXXIII, Fig. $7, p^{\prime \prime \prime}$., and Pl. XXXV, Fig. $17, d$. It occurs more especially opposite to a leaf-trace which is preparing to come out through the zone of secondary wood, and when the two bundles of a trace have escaped from the xylem and are passing outwards and upwards through the pericycle and cortex into the leaf, they are accompanied by two arcs of this tissue. This is clearly seen on Pl. XXXIV, Fig. 8, which shows a pair of leaf-trace bundles passing out through the pericycle and carrying with them the dark cells, $c$. From their position at the outer limit of the secondary phloem, and localization opposite to the primary xylem groups of the leaf-trace bundles, it seems probable that this tissue really represents the primary phloem groups of the original bundles.

The phloem, as a whole, appears to be much like that of Cordaites, which consists, according to Renault, of sieve tubes and phloem parenchyma with 'gum' tubes, and, in some forms, bast-fibres. ${ }^{1}$ In Poroxylon the structure of the phloem is not the same in different species. In $P$. Edwardsii the secondary phloem is extraordinarily well preserved, and is made up of distinct alternate tangential bands of sieve tubes and of parenchyma, with broad medullary rays consisting of large cells. Nothing of this kind is found in Mesoxylon Sutcliffii. Indeed, the phloem is of quite a distinct type, as was at once recognized by Professor Bertrand (one of the authors of the original detailed description of Poroxylon), to whom a section of Mesoxylon Sutcliffi $i$ was submitted by Dr. D. H. Scott for examination.

1 Renault, Bassin houiller et permien d'Autun, \&c., p. 335. 
In Poroxylon Boysettii, however (which includes the specimens first discovered, and described by M. Renault in I 879), the phloem has a different structure, ${ }^{1}$ showing that the regular structure of the phloem described above is only a specific character in Poroxylon.

Surrounding the phloem there is a fairly thick band of tissue which may be interpreted as the pericycle. In transverse sections (see Pl. XXXIII, Fig. $7, p e$, and Pl. XXXV, Fig. I $7, p e$.) this zone is seen to consist mainly of rather large cells, most of which are filled with brown contents, and without any obvious arrangement in radial rows. Longitudinal sections (Pl. XXXIV, Fig. I3, pe.) show that this tissue consists chiefly of short parenchymatous cells without any very definite arrangement excepting that in some places the elements occur in vertical rows. There are also a number of tubular elements occupied by brown contents and probably formed from vertical rows of cells.

The pericycle is easily distinguished from the phloem in transverse sections by the larger size of its cells and the absence of radial arrangement ; and also from the cortex outside it (Pl. XXXV, Fig. I7, i.c.) by the abundant contents of the cells. In longitudinal sections it is distinguished from the phloem by the shortness of most of its contents-filled cells as well as by the larger size of these elements. The pericycle tissue closely resembles the greater part of the persistent outer part of the pith (Pl.XXXIII, Fig. 6, $p^{\prime \prime}$.), from which it mainly differs in the presence of 'vessels ' with brown contents which are absent from the pith, and in the frequent great disturbance of the tissues resulting from the emergence of the numerous leaf-traces.

The leaf-traces in the phloem and pericycle. As we have seen (p. 399), the leaf-trace bundles when traversing the zone of secondary xylem ascend very slowly, but on reaching the phloem the inclination again increases, so that in transverse sections of the stem they are cut nearly transversely. Before the exit of the xylem of the trace bundles from the secondary wood, and even before they have left the perimedullary position, considerable disturbance is visible in the phloem zone opposite to the emerging bundles, and the before-mentioned arcs of dark cells (p. 4OI) take up their position at the outer side of the phloem.

When once they are free from the xylem cylinder the leaf-trace bundles show a distinct collateral structure with external phloem, and this structure is preserved as far out as the bundles can be followed into the leaves. On reaching the phloem and pericycle, each bundle experiences a marked tangential dilatation, and the centrifugal xylem of the bundles becomes of a much less compact character than that of the bundles on the margin of the pith, or of the secondary xylem of the stele, and consists of a number of narrow bands of tracheides separated by broad medullary rays, as shown in the bundles seen on Pl. XXXIV, Fig. 8, s.b. At the same time the primary 


\section{Maslen.-The Structure of Mesoxylon Sutcliffii (Scott). 403}

centripetal xylem of each original bundle divides into a number of small patches lying within, but usually separated by a small amount of parenchyma from, the wedges of centrifugal wood (Pl. XXXIV, Fig. 8, p.b.). The enlargement and tangential dilatation of the bundles is preparatory to their division into two, which takes place in the pericycle, a strictly collateral structure being preserved.

Pl. XXXIV, Fig. 8, shows a pair of leaf-trace bundles in the inner part of the pericycle. Each of the bundles shows the above-mentioned characteristics, although the actual division of the bundles has not yet taken place excepting in the xylem portion. Each bundle has a tangential width of about $0.9 \mathrm{~mm}$., which is more than double that of a bundle at the margin of the pith. Outside the xylem of the bundles is the phloem, ph.b., similar to and continuous with, that of the stem, and outside this again the arc of primary phloem, c., before mentioned (p. 401).

Surrounding the xylem portion of the bundles there occurs a delicate conjunctive tissue, $b$, which is doubtless the same as that already mentioned as occurring around the trace bundles at the margin of the pith, and which is there usually represented by an empty space (Pl. XXXIII, Fig. 3, s.). Outside this there is a relatively broad sheath of cells with contents (Pl. XXXIV, Fig. 8, s.) surrounding the bundles, especially internally and laterally (at the level shown on Pl. XXXIV, Fig. 8, it is practically absent on the outer side of the bundle), and this sheath accompanies the bundles out into the cortex. The tissue composing this sheath is probably continuous along the course of the leaf-trace with the tissue forming the outer part of the pith, which thus becomes continuous with the very similar tissue of the pericycle. Confirmation of this is found in the tangential section of the wood of the stem described on p. 399 ; the slide shows two leaf-trace bundles cut transversely in the xylem, and each of these is accompanied by a tissue similar to that of the outer pith.

A similar division of each leaf-trace bundle into two in the pericycle, which is here described in Mesoxylon Sutcliffii, also takes place in many species of Cordaites, in which the leaf-trace is also a double one. A similar division also takes place in the other species of Mesoxylon described in our preliminary note; in one species, however- $M$. platypodium-each of the bundles had already divided, as regards its primary (centripetal) xylem, even before leaving the wood. ${ }^{1}$

In Lyginodendron, and in Calamopitys, division also takes place in the pericycle, but in these forms there is only one trace bundle to divide, as the trace when passing through the secondary wood from the perimedullary position is single. In Poroxylon, however, which agrees with Mesoxylon in the possession of paired leaf-traces at the margin of the pith, according to MM. Bertrand and Renault, each leaf received from the stem a single large

\footnotetext{
1 Preliminary Note, loc. cit., p. 239.
} 
bilobed bundle (i.e. a double leaf-trace) at the base of the petiole, and division of this did not take place until after the bundles had entered the leaf. It thus appears that in the early division of the leaf-trace bundles, as in many other respects, Mesoxylon is much nearer to Cordaites than to any other form, while to a certain extent it combines characters found in Poroxylon, Lyginodendron, and Calamopitys.

\section{The Cortex And Leaf-Bases.}

The primary cortex and leaf-bases of Mesoxylon Sutcliffi $i$ consist of parenchyma traversed in the outer part by strengthening bands similar to those of many other Palaeozoic plants.

The thickness of the cortex between the leaf-bases can hardly be determined, as the surface of the stem is practically covered with bases of leaves.

The junction between the pericycle and the cortex is not a very sharp one, although it is as a rule fairly well defined by the difference between the contents-filled cells of the pericycle and the empty-looking ones of the cortex which are shown on Pl. XXXIII, Fig. 7, i.c., and Pl. XXXV, Fig. I7, i.c. The cells of the inner part of the cortex are also usually somewhat smaller than those of the pericycle. Longitudinal sections show that the cells of the inner cortex are arranged in more or less vertical rows. The outer portion of the primary cortex and the leaf-bases consist of much larger cells reaching a diameter of $0.2 \mathrm{~mm}$., and a rough arrangement in vertical rows is sometimes visible in this portion also. At the outer limit of the cortex there is some trace of a small-celled epidermal layer.

The Dictyoxylon outer cortex contains a number of strengthening bands arranged as more or less radial plates as seen in transverse sections

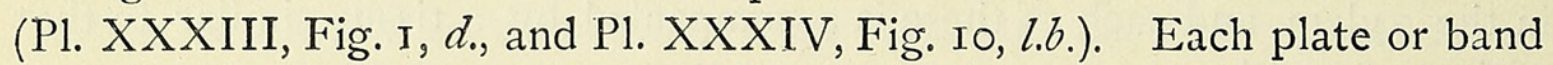
consists of much smaller but thicker-walled elements than those forming the rest of the outer cortex. In longitudinal sections the plates are seen to be composed of much elongated fibres with oblique ends, very different from the empty, often radially elongated, cells in which the bands are enclosed.

Secondary cortical tissues were formed in abundance in Mesoxylon Sutcliffii, and a number of successive periderms are seen which ultimately cut right down to the pericycle, or even deeper still. Numerous wavy bands of periderm are seen on Pl. XXXIII, Fig. I, pm., and Pl. XXXIV, Fig. 9, $p^{\prime} ., p^{\prime}$., Fig. Io, $p^{\prime}$. Secondary cortical tissue was formed on both sides of the phellogen and often in about equal quantity. In some places there is a marked difference between the elements formed on the outer side and those developed on the inner side of the phellogen ; the former being radially flattened cells with thicker walls, and the latter often radially elongated cells with thinner walls.

In the deep-seated origin of the periderm Mesoxylon Sutcliffi $i$ resembles 
both Poroxylon and Lyginodendron. In both these genera the phellogen arises in the pericycle, and in Lyginodendron periderm bounds the pericycle externally, forming an almost continuous layer, which arches out opposite to the leaf-traces just as is usually also the case in Mesoxylon Sutcliffii (P1. XXXIV, Fig. Io). In the new form, however, the periderms are formed in a much more irregular manner, at varying depths, cutting across the cortex and leaf-bases in arcs.

The leaf-trace bundles continue to divide in traversing the cortex. Pl. XXXIV, Fig. 9, shows a leaf-trace in the inner part of the cortex ; each of the original bundles is now represented by three, so that the trace as a whole consists of six bundles. On Pl. XXXIV, Fig. IO, another trace is shown somewhat further out in the cortex, but still consisting of six bundles. Each of the bundles possesses the same characters as were described above for the bundles in the pericycle, excepting that the bundle sheath is now a complete one, that part of it on the outer side of the bundle consisting of tissue which has been carried out from the pericycle (cp. p. 403). In some slides a trace consisting of as many as eight bundles may be seen in the cortex, or near to the junction between the cortex and the leaf-base.

The leaf-bases and petioles. As already described, in Mesoxylon Sutcliffii seven or eight of the large leaf-bases serve to cover the stem, as seen in transverse sections (Pl. XXXIII, Fig. I). The general structure of the leafbases has been already given, and it remains only to describe now the leaftrace bundles in the adherent leaf-bases and in the free petioles. Division continues as the trace is followed outwards from the cortex, and ten or more bundles may be seen in the leaf-base while it is still adherent to the stem.

The lower portion of the free petiole is sometimes preserved in Mesoxylon Sutcliffi, and one of these is shown on PJ. XXXV, Fig. I8, cut in transverse section. The petiole shown in the figure is of flattened form and has a length of nearly $9 \mathrm{~mm}$. and a width of nearly $2 \mathrm{~mm}$. Its outer surface presents a more or less crenulated margin, while the inner side is torn and disorganized. The petiole itself appears to consist entirely of parenchymatous cells, many of which possess very dark contents. The petiole shown in Fig. I 8 shows a row of about ten bundles, some of which present the appearance of being about to divide. As many as sixteen bundles have been seen in a petiole within a very short distance of its insertion on the stem, showing that the division of the bundles continues to take place after their entry into the leaf.

One of the bundles in the petiole shown on Pl. XXXV, Fig. 18 , is also shown more enlarged on Pl. XXXV, Fig. I9. Only the xylem is preserved. The bundles still preserve their original collateral structure, and in this respect Mesoxylon Sutcliffi agrees with both Poroxylon and Cordantes. The bundles in the petiole still possess a considerable amount of radially arranged xylem, $x$., but it is distinctly less in quantity than in the more deeply seated 
portions of the bundles. On the other hand, the inner wood of the bundle has increased in relative size, and it now equals, or nearly equals, the radially arranged elements in amount. Moreover, evidence of mesarch structure in the inner wood is somewhat more clearly shown than is the case in other regions. Some of the elements which lie external to the thin-walled cells which mark the position of the protoxylem, $p x$., probably belong to the inner wood. Unfortunately, we have no longitudinal sections passing through the bundles in the petioles, and so we have been unable to confirm our observations on the transverse sections. In Fig. 19 the disorganized phloem tissue is represented at $p$., and surrounding the bundle are some of the contents-filled cells of the leaf tissue. In the probable possession of mesarch leaf bundles our plant agrees with Poroxylon, some species of Cordaites, and Lyginodendron among fossil plants, as well as with the modern Cycads. Dr. M. C. Stopes has shown that in some species of Cordaites (C.principalis, Germ.) the centrifugal part of the xylem is absent, so that the leaf bundles are exarch, and she suggests that 'as a Cordaitean character possibly too much weight may have been attached to the presence of centrifugal xylem in the foliar strand'. 'From an examination of the original figures of structure specimens of Cordaitean leaves given by Renault, Grand'Eury, and Felix, she concludes that 'the majority of known Cordaitean leaves appear to be without centrifugal xylem', and compares the leaf bundles of most species of Cordaites with the exarch petiolar bundles of Medullosa. ${ }^{2}$ The bundles of Cordaites described by Dr. Stopes are far out in the flattened lamina of the leaf, while the leaf bundle of Mesoxylon Sutcliffii shown on Pl. XXXV, Fig. 19, is quite near to the base of the petiole; until sections of the lamina of Mesoxylon Sutcliffi have been identified, it will be impossible to determine to what extent the centrifugal portion of the bundles persists out into the leaves.

Exarch bundles are also found at the edges of the leaves of Poroxylon, while the more central main bundles are mesarch. ${ }^{3}$

\section{The Axillary Buds.}

The characteristic axillary buds of Mesoxylon Sutcliffi $i$ have already been briefly described. The transverse section represented on P1. XXXIII, Fig. I, shows two buds, a.b., a.b., as well as bud-steles, a.b.s., passing out through the cortex to buds which arise in the axils of leaves at a level above that of the plane of section. P1. XXXIV, Fig. Io, shows part of a transverse section of a stem with a bud-stele, a.b.s., in the cortex cut nearly transversely, outside which is a row of six leaf-trace bundles and the subtending leaf-base into which the bundles will pass. The same bud-stele is shown on

1 Dr. M. C. Stopes, On the Lear-structure of Cordaites. New Phytologist, vol. ii, 1903, p. 97.

3 Bertrand and Renault, Sur les Poroxylons, loc. cit., p. 354 . 
Maslen.-The Structure of Mesoxylon Sutcliffii (Scott). 407

Pl. XXXIV, Fig. II, more highly magnified, and it illustrates the general oval form (elongated tangentially) and the other general characters of the stele. The xylem portion of this stele measures about $0.70 \mathrm{~mm} . \times 0.35 \mathrm{~mm}$, and its flattened form is clearly natural and not due merely to the compression of the stem in which it is enclosed, since the latter shows but little compression, and that in a different plane from that of the bud-stele. The stele consists of a fairly large medulla, p., forming a continuous tissue and surrounded by a zone of radially arranged xylem elements, $x$, separated by relatively broad medullary rays, m.r. The xylem elements of the bud-steles are much smaller than those of the leaf-trace bundles or of the continuous ring of secondary xylem of the main axis, and this difference in size of the tracheides appears to furnish a ready means of distinguishing the bud-steles from the leaf-trace bundles when they are seen in longitudinal sections.

It has not been possible to distinguish any centripetally developed xylem elements in the bud-steles, although they are probably present, nor is any division into distinct bundles seen as long as the stele is embedded in the tissues of the main axis.

As already mentioned, twin bud-steles are not infrequently seen embedded in the pericycle or the inner cortex of Mesoxylon Sutcliffii, as shown on Pl. XXXIV, Fig. I2. Sections cut from the same specimen at a somewhat higher level show only one larger stele, and the two steles in the lower section doubtless result from the division of this one as it passes slowly downwards and inwards. Division of a bud-stele is also shown in one of the longitudinal sections. ${ }^{1}$ In all probability the oval tangentially elongated form of the bud-stele shown on Pl. XXXIV, Fig. II, is to be correlated with its approaching division into two steles.

In many transverse sections, however, only a single bud-stele is shown, even when quite close to the secondary wood, which seems to indicate that the division of the bud-stele, if it took place, often occurred while it was traversing the secondary wood of the main axis. This division must have taken place if the connexion of the vascular tissues of the branch with those of the main axis was similar to that of Poroxylon, in which the vascular system of the branch was inserted on the two bundles of the main axis, between which the trace of the subtending leaf passed out. Unfortunately, none of the longitudinal sections afford clear evidence of the actual mode of insertion of the bud-steles on the bundles of the main axis. In connexion with the twin axillary steles of Mesoxylon Sutcliffii, it is interesting to note that in another species-M. platypodium - a form with very broad leafbases, there are always two axillary steles corresponding to a single leaf. ${ }^{2}$

Following the bud-stele outwards into the axis of the branch (bud), some interesting modifications of structure are seen, and it is particularly interesting to be able to compare the structure of the extremely young

$$
1 \text { Slide No. } 2674 \text { (S). }
$$

2 Preliminary Note, p. 239. 
stem of the bud with that of the ordinary mature stem. Pl. XXXVI, Fig. 20, shows a transverse section of an axillary bud magnified about 40 diameters. Surrounding a relatively large continuous pith, $p$, is a ring of some five or six minute but distinct bundles, $b$., separated by broad medullary rays, m.r. The xylem of the bundles consists mainly of rows of very small tracheides, and within these there is some evidence of minute patches of irregularly arranged elements, evidently corresponding to the centripetally developed wood of the bundles of the main axis. Outside the wood some rows of thin-walled phloem elements are visible.

Between the larger bundles, and in the medullary rays, are seen small bundles (P1. XXXVI, Fig. 20), which are evidently leaf-trace bundles, passing out to the bud-scales, and similar ones are also seen traversing the pericycle and cortex (Fig. 20, l.t., \&c.). Each of these minute leaf-trace bundles appears to consist of about half a dozen very small tracheides without radial arrangement, and to be composed entirely of the centripetally developed xylem sometimes seen at the margin of the pith.

No arrangement of the leaf-trace bundles in pairs is visible, although opposite to each 'gap' between the main bundles two leaf-trace bundles are usually seen, one of these, however, being much further out than the other. The wood at this early stage in the development of the 'branch' is of a much less dense character, with broader medullary rays, than is characteristic of the ordinary secondary xylem of the mature stem of Mesoxylon and other Cordaiteae, while it more resembles the less dense centrifugal wood forming part of the leaf-trace bundles, which may be partly of primary rather than of secondary origin (ante, p. 394). Indeed, it seems probable that the whole of the xylem of the bundles in the section shown on Pl. XXXVI, Fig. 20, is best regarded as primary wood.

Outside the stele occurs a relatively broad band (P1. XXXVI, Fig. 20, pe.) consisting of small cells, some of which possess dark contents. This tissue, which closely resembles the pith in appearance, probably corresponds with the tissue which has been distinguished as the pericycle in the main axis. Beyond this tissue appears a larger-celled cortex, c. Pl. XXXVI, Fig. 20, also shows some of the closely-packed leaves or scales, s., s., of the bud. Another somewhat better preserved section of a bud-scale is shown on Pl. XXXVI, Fig. 2I. It shows a small-celled epidermal layer, e.; a distinct hypodermal tissue near the outer surface, consisting of small thick-walled cells, $h_{\text {. ; }}$ a relatively large-celled mesophyll tissue, $m$., and two very minute bundles, $b ., b$., close together near the centre of the leaf, each consisting of about half a dozen or fewer exceedingly small tracheides about $0.007 \mathrm{~mm}$. in diameter.

In all the sections of Mesoxylon Sutcliffii which have been examined, the buds appear to be in almost exactly the same stage in development; in no case has a bud grown into a distinct branch. Presumably they were 
resting buds of some kind, but whether vegetative or reproductive it has been impossible to determine. In the only other species of Mesoxylon in which axillary members are present, viz. $M$. multirame, a leafless axillary branch, resembling a phylloclade, is present in most of the leaf axils ${ }^{1}$; these are very different from the little buds of $M$. Sutcliffi, and evidently the two organs had quite distinct functions.

An epitome of the generic characters of Mesoxylon has already been given (see pp. $3^{84}, 3^{85}$ ), and the following is a brief diagnosis of the species described in the present paper. A full account of the other species of Mesoxylon will be given in a forthcoming paper by Dr. D. H. Scott, F.R.S.

VIII. Mesoxylon Sutcliffii (Poroxylon Sutcliffi, Scott, Studies in Fossil Botany, 2nd Edition, I909, p. 51 I, Fig. I84).

Only the stem and bases of leaves known.

Leaf-bases crowded, completely covering the surface of the stem.

Pith large (diameter nearly half that of the stem as a whole), discoid, with a persistent outer zone.

Twin-bundles of the leaf-traces, when they reach the margin of the pith, separated by tissue about equal in width to that of one of the bundles, and remaining separate when traced downwards through several internodes before fusing; subdividing in the pericycle and cortex to form about eight bundles in all.

Centripetal xylem distinct, persisting below the point of fusion of the two leaf-trace bundles.

Tracheides of the leaf-traces (centripetal and centrifugal), spiral or scalariform ; those of the intermediate secondary wood pitted, except perhaps at the extreme inner margin.

Medullary rays of the secondary xylem uniseriate, usually I- 6 cells in height.

Dictyoxylon zone of cortex somewhat narrow.

Petiole of leaf flattened, containing about sixteen bundles near its insertion on the stem.

An axillary bud present in the axil of every leaf.

Roof nodules; Shore, Littleborough.

\section{Conclusions.}

Mesoxylon Sutcliffi (as well as the other species of Mesoxylon) exhibits structural characters intermediate between those of Cordaites and Poroxylon, but on the whole stands much nearer to the former genus; indeed, it seems not improbable that many of the familiar Cordaitean leaves which occur in the English Coal Measures may really belong to the new genus. 
A summary of the most important characters in which Mesoxylon Sutcliffii resembles, and differs from, Poroxylon and Cordaites will serve to make this clear.

Mesoxylon Sutcliffi Resembles Poroxylon in the possession of centripetal xylem strands forming part of the leaf-trace bundles in the perimedullary position, as well as in the bundles passing out to the leaves; in the paired leaf-trace bundles, which remain separate for a considerable distance (several internodes) after their entry into the inner part of the stele; in the persistently collateral structure of the leaf-traces from the perimedullary position right out into the leaves; in the possession of rows of bordered pits on the radial walls of the secondary xylem elements; in the spiral arrangement of the leaves; in the mesarch bundles in the leaves; in the presence of numerous axillary buds, \&c.

Mesoxylon Sutcliffi DIFFERS from Poroxylon in the discoid pith; in the fact that all the xylem elements of the leaf-traces, both centripetal and centrifugal, consist of spiral or scalariform elements, whereas in Poroxylon not only are the centrifugal elements of the leaf-traces provided with rows of bordered pits, but the more internal portion of the centripetal xylem is pitted also; in the denser character of the secondary xylem, which consists of smaller elements with narrower or shorter medullary rays; in the structure of the phloem; in the divisions of the leaf-trace bundles in the pericycle and cortex before they enter the leaf; in the crowding of the leaves on the stem, \&c.

The points of ReSemblance between Mesoxylon Sutcliffii and Cordaites are very numerous, and are generally those in which it differs from Poroxylon. They may be summarized as follows: the large size of the pith; the discoid structure of the inner pith, which is found in most species of Cordaites and probably in all the forms of Mesoxylon yet recognized; the secondary xylem is practically identical in both genera; the phloem is similar; the division of the paired leaf-trace bundles in the pericycle and cortex, so that a number of bundles entered the base of the leaf, \&c.

The most important of the DIFFERENCES between Mesoxylon Sutcliffii and Cordaites is found in the presence of the strands of centripetal wood surrounding the pith in Mesoxylon, whereas in Cordaites the whole of the wood of the stele is described as being centrifugal in development.

All the species of Mesoxylon which were described in our preliminary note agree in the possession of similar strands of centripetal xylem, although there is some variation in its amount, in the rapidity with which it dies out when traced down the stem, as well as in the degree of separation of the twinbundles when they reach the perimedullary position after coming in from the leaves (see p. 396). In $M$. multirame the centripetal xylem dies out rather rapidly after the leaf-trace has reached the pith, so making a nearer approach to the condition which we get in Cordaites itself, in which the 
centripetal wood of the leaf-traces which is present in the outer part of their course is entirely lost before they reach the boundary of the pith. As Dr. Scott says: "In the Cordaiteae the old "Cryptogamic" or centripetal wood appears to have been on the verge of extinction, and its presence or absence may here be of little taxonomic significance.' ${ }^{1}$ This being the case, Mesoxylon, which resembles Cordaites in so many of its other characters, may best be included in the family Cordaiteae. The affinity of the French Poroxyleae with the Cordaiteae has been recognized ever since the description of the forms by MM. Bertrand and Renault. The discovery of the leaves of Poroxylon, and the attribution to this form of the platyspermic seed known as Rhabdocarpus, Br., by Grand'Eury, if the discovery is confirmed, considerably strengthen the affinity otherwise indicated between the Poroxyleae and Cordaiteae. Marks of similarity between the Poroxyleae and Lyginodendron and Heterangium were also indicated by the French observers, and at the present time it is well recognized that the agreement in the structure of the stem between Poroxylon and Lyginodendron is in many respects a close one, although, with a common type of stem structure, there existed in the one form a foliage type which in form and structure resembled that of Cordaites and recent megaphyllous Gymnosperms, while in the other the foliage was in every respect that of a fern. With Calamopitys Saturni, Unger, again, Poroxylon has much in common.

In consequence of the obvious affinities of Poroxylon in both directions, and of the very perfect manner in which the tissues have been preserved, and the very detailed account which we owe to MM. Bertrand and Renault, the Poroxylons have come to possess a crucial significance in the discussion of the relation of the Cordaiteae to the Pteridosperms, and so on that of the broader question of the derivation of the higher Gymnosperms.

The species of Poroxylon were described from deposits of PermoCarboniferous Age, and thus can hardly be considered as forming an actual link between families which had been fully differentiated long before that time; it is therefore particularly interesting to find, at a much lower horizon-the Lower Coal Measures of Lancashire-forms which, while possessing centripetal wood as in Poroxylon, are in other respects much closer to Cordaites, and probably stand nearer to the direct line of Cordaitean descent. Another Coal-Measure plant, Dadoxylon Spenceri, Scott, already briefly described (p. 395), although differing from Mesoxylon Sutcliffii and Cordaites in the small size of the pith, resembles Mesoxylon in so many other respects that it may prove to be closely related. Pitys antiqua, again, a Lower Carboniferous form (see p. 395), agrees with Mesoxylon in the structure of its wood excepting for the greater width of the medullary rays and the definitely mesarch structure of its single xylem strands surrounding the pith; judging from the anatomical structure of the pith and wood (the

${ }^{1}$ Studies, and Edition, p. $5^{26}$. 
only parts yet known), it probably stands somewhat nearer to the Pteridosperms than Mesoxylon does, although well on the way towards the typically Gymnospermous family of the Cordaiteae. A feature of the Cordaiteae and of the plexus of form connecting this family with the Pteridosperms is the double leaf-trace shared at the present day by Ginkgo. Recent work on the occurrence of the double leaf-trace in Gymnosperms and in angiospermous seedlings, ${ }^{1}$ as well as its common occurrence in so many Palaeozoic plants, suggests that it may have considerable taxonomic importance.

The fusion of the twin-bundles of the leaf-trace which in Lyginodendron and Calamopitys takes place in the pericycle, is pushed further back in the higher forms which lead on to the Cordaiteae. In most of these forms (Poroxylon, Dadoxylon Spenceri, Mesoxylon) fusion does not take place until after the perimedullary position has been reached and until the trace has penetrated a considerable distance down the stem, the centripetal xylem persisting until after fusion has been effected. In one form of Mesoxylon, however, viz. $M$. Lomaxii, the strongly converging twin-bundles fuse into one immediately on reaching the pith. ${ }^{2}$ As Dr. Scott has pointed out, the division of the trace extends, on the whole, lower down the stem in the later forms. ${ }^{3}$

By the study of Mesoxylon and the other more ancient Cordaitean stems we are able to trace some of the stages in the gradual extinction of the centripetal wood of their Cryptogamic ancestors, a process which appears to have been completed in the true Cordaites. The endarch structure thus reached in Cordaites has persisted as a characteristic feature in the anatomy of the stems of the higher plants.

In conclusion, I wish to tender my grateful thanks to Dr. D. H. Scott, M.A., F.R.S. After the preparation of our joint preliminary note on Mesoxylon it had been intended to publish a full description of all the species under our joint names. As this work could not have been completed for some considerable time, Dr. Scott very generously suggested that I should publish a detailed account of $M$. Sutcliffi $i$ first. Throughout the progress of the work I have had the invaluable help of Dr. Scott's suggestions and criticism. I also wish to thank Mr. L. A. Boodle, F.L.S., who has kindly allowed the work to be done at the Jodrell Laboratory, Kew, and who also supplied some of the photographs used in the plates. The other photographs are by Mr. W. Tams.

All the specimens were discovered by Mr. James Lomax in the Shore material, and the sections cut by him.

${ }^{1}$ Miss E. N. Thomas, A Theory of the Double Leaf-trace, founded on Seedling-structure. New Phytologist, vol. vi, 1907, p. 77 .

${ }^{2}$ Scott and Maslen, loc. cit., p. 239.

${ }^{3}$ Studies, 2nd Edition, p. 652 . 


\title{
EXPLANATION OF PLATES XXXIII-XXXVI.
}

\author{
Illustrating Mr. A. J. Maslen's paper on Mesoxylon Sutcliffii.
}

\section{PLATE XXXIII.}

Fig. I. Transverse section of stem, showing the large pith, the ring of wood and phloem, the cortex with attached leaf-bases, and two axillary buds. c.p., central pith; p.p., peripheral pith; l.t., l.t., \&c., paired leaf-trace bundles at the margin of the pith (in some of these the two bundles are widely separated, in others they are closely approximated, and in yet others the two have fused laterally into one bundle); s.x., ring of secondary xylem; p., phloem ; pe., pericycle; $l^{\prime} . t^{\prime}$., \&c., leaftraces in the phloem and pericycle; $d$., Dictyoxylon outer cortex; pm., periderms; l.b., leaf-bases, of which seven are seen completely enclosing the stem; a.b., a.b., axillary buds, one of which is accompanied by the subtending leaf-base; a.b.s., axillary bud-stele in the cortex; s., space in secondary xylem. Slide No. 262 I (S). ${ }^{1}$ Magnification just over 3 diameters.

Fig. 2. Radial longitudinal section of stem, showing discoid pith, \&c. c.p., central discoid pith; $p . p ., p . p$. , peripheral pith; l.t., leaf-trace bundle at margin of pith ; s.x., secondary xylem with a central space due to disappearance of the tissue by disorganization (on the right-hand side of the section nearly the whole of the wood has been destroyed); $p$., phloem ; pe., pericycle ; $l^{\prime} . t^{\prime}$., leaf-trace bundle passing into leaf-base ; $d$., strengthening bands of Dictyoxylon outer cortex ; l.b., l.b., leaf-bases; a.b., a.b., leaves belonging to axillary buds; a.b.s., bud-stele in the phloem or pericycle ; a., position of abscission layer at base of petiole. Slide No. 2668 (S). Magnification 4 diameters.

Fig. 3. Transverse section of a leaf-trace at the margin of the pith with the two bundles widely separated. s.b., centrifugal xylem of the bundles; $p . b$., centripetal xylem of the bundles; $p x$., position of protoxylem; s.x., secondary xylem between the bundles; s., space formerly occupied by delicate conjunctive parenchyma; $p^{\prime}$., empty thin-walled cells of outer pith; $p^{\prime \prime}$., thicker walled cells of outer pith with contents. Slide No. 2634 (S). Magnification nearly 40 diameters.

Fig. 4. Transverse section of a leaf-trace at the margin of the pith with the two bundles closely approximated. Reference letters as in Fig. 3 ; also pa., delicate parenchyma between centripetal and centrifugal xylem of bundles; $p^{\prime \prime \prime}$., outer pith cells with very dark contents; $p^{\prime \prime \prime \prime}$., small emptylooking cells of outer pith next the xylem. Slide No. ${ }_{2} 6_{53}(\mathrm{~S})$. Magnification about 40 diameters.

Fig. 5. Transverse section of a leaf-trace at the margin of the pith with the centrifugal xylem of the two bundles fused laterally into one, although the two masses of centripetal xylem are still separate. s.b., centrifugal xylem; $p . b$., centripetal xylem; m.r., wide medullary rays in centrifugal xylem of bundles; $m^{\prime} . r^{\prime}$., narrow medullary rays in secondary xylem beyond the bundles; $p^{\prime \prime \prime}$., outer pith cells with very dark contents. Slide No. 2636 (S). Magnification about 40 diameters.

Fig. 6. Longitudinal section passing through the two bundles of a leaf-trace at the margin of the pith. l.t., l.t., leaf-trace bundles; p.b., denser centripetal xylem of bundle; s.b., less compact centrifugal xylem of bundle consisting of undulating tracheides separated by relatively broad medullary rays; s. $x$., secondary xylem of stem consisting in the outer part, $a$, of closely packed straight tracheides with narrow medullary rays, and in the inner part, $b$, of more loosely arranged elements with broader medullary rays ; $p^{\prime}$., empty cells of outer pith ; $p^{\prime \prime}$., cells with contents of outer pith. Slide No. 2667 (S). Magnification 20 diameters.

Fig. 7. Transverse section of outer part of secondary xylem, phloem, and pericycle. s.x., secondary xylem; $p$., phloem; $p e$., pericycle; $p^{\prime}$., square cells of phloem with very dark contents ; $p^{\prime \prime}$., cells with paler contents ; $p^{\prime \prime \prime}$., dark cells at outer limit of phloem ; $i . c$. , cells of inner part of cortex. Slide No. 2637 (S). Magnification about 40 diameters.

\section{PLATE XXXIV.}

Fig. 8. Transverse section, showing a leaf-trace in the inner part of the pericycle. The xylem portions of the bundles have already divided. s.b., centrifugal xylem of leaf-trace bundles; p.b., centripetal xylem of leaf-trace bundles; ph.b., phloem of bundles still undivided; $c$, , cells with dark

1 The letter (S) following the slide number signifies that the sections are in Dr. D. H. Scott's collection. 


\section{I4 Maslen.-The Structure of Mesoxylon Sutcliffii (Scott).}

contents at outer limit of phloem of bundles; $b$., delicate conjunctive tissue; $s$, sheath of cells with contents surrounding the bundles : s.x., secondary xylem of stele; $p$., phloem of stele; pe., pericycle ; i.c., cells of inner cortex. Slide No. 2615 (S). Magnification about 20 diameters.

Fig. 9. Transverse section, showing a leaf-trace in the inner part of the cortex. Each of the original bundles has divided into three. l.t., leaf-trace bundles; s., sheath surrounding bundles; s.x., secondary xylem of stele; i.c., cells of inner cortex ; $p^{\prime}$., $p^{\prime}$., periderms; a.b.s., axillary budstele just escaping from the secondary xylem of the stele. Slide No. 2625 (S). Magnification about Io diameters.

Fig. I0. Transverse section, showing a bud-stele in the cortex with its subtending leaf-base and a row of six leaf-trace bundles passing into it. a.b.s., axillary bud-stele; l.t., l.t., two of the leaf-trace bundles; s.x., outer part of secondary xylem of stem; l.b., leaf-base; $d$., Dictyoxylon bands ; $\not p^{\prime}$., periderm. Slide No. 2653 (S). Magnification 9 diameters.

Fig. I I. The bud-stele shown in Fig. Io more highly magnified. $p$. , pith; $x$, xylem of bud-stele; m.r., inedullary rays. Slide No. $26_{53}(\mathrm{~S})$. Magnification about ${ }_{4} 40$ diameters.

Fig. I 2. Transverse section, showing twin bud-steles in the cortex. b., bud-steles; l.t., leaftrace bundles; s.x., secondary xylem. Slide No. 2657 (S). Magnification about 34 diameters.

Fig. I3. Longitudinal section of the outer part of the stem, showing part of a leaf-base with the bud-stele in its axil, \&c. a.b.s., bud-stele; $l^{\prime} . t^{\prime}$., leaf-trace bundle; s., sheath enclosing leaf-trace bundles; s.x., secondary xylem of stem; p., phloem of stem; pe., pericycle; $c$., cortex ; l.b., leafbase; $a$., position of abscission layer at base of petiole. Slide No. 2667 (S). Magnification about 8 diameters.

\section{PLATE XXXV.}

Fig. I4. Longitudinal section of one of the leaf-trace bundles also shown on Pl. XXXIII, Fig. 6, showing tracheides and medullary rays. $t$., tracheides; m.r., medullary rays. Slide No. 2667 (S). Magnification 370 diameters.

Fig. I 5. Part of one of the tracheides of the secondary xylem in radial section. Slide No. 267I (S). Magnification about 400 diameters.

Fig. I6. Tangential section of the secondary xylem, showing the tracheides and narrow medullary rays. $t$. , tracheides ; m.r., medullary rays. Slide No. $2665(\mathrm{~S})$. Magnification about 400 diameters.

Fig. I7. Transverse section of the phloem, pericycle, \&c. s.x., outer part of secondary xylem consisting of tracheides and narrow medullary rays ; $c$., cambium cells; $p$., phloem consisting of thin-walled elements (? sieve tubes), and phloem parenchyma, $a$; square cells with very dark contents, $b$; cells with paler contents, $c$; and narrow medullary rays, m.r.; $d$. , cells with dark contents at outer limit of phloem; pe., pericycle; i.c., cells of inner cortex. Slide No. 2633 (S). Magnification about 75 diameters.

Fig. 18. Transverse section of petiole, showing a row of ten bundles each with centrifugal and centripetal xylem. i.x., inner xylem of bundle; o.x., outer xylem of bundle ; 0 , outer (lower) side of petiole. Slide No. 263I (S). Magnification about 12 diameters.

Fig. I9. Transverse section of one of the bundles shown in Fig. 18 more highly magnified. Only the xylem is preserved. s.x., outer xylem elements in radial rows; $p x$., protoxylem ; $p^{\prime} \cdot x^{\prime}$., centrifugally developed primary xylem elements; $p^{\prime \prime} . x^{\prime \prime}$., centripetally developed primary xylem elements; $\not p$. disorganized phloem. Slide No. ${ }^{26} 3_{1}$ (S). Magnification about 230 diameters.

\section{PLATE XXXVI.}

Fig. 20. Transverse section of axillary bud. p., pith ; b., bundles ; m.r., medullary rays ; .t., l.t., \&c., leaf-traces; pe., pericycle ; c., cortex ; s.s., \&c., scales of bud. Slide No. 2620 (S). Magnification 40 diameters.

Fig. 21. Transverse section of one of the leaves of an axillary bud. e., epidermis; $h$, hypodermal layer; $m$., mesophyll ; $b$., $b$, , bundles. Slide No. $263_{2}$ (S). Magnification 80 diameters. 


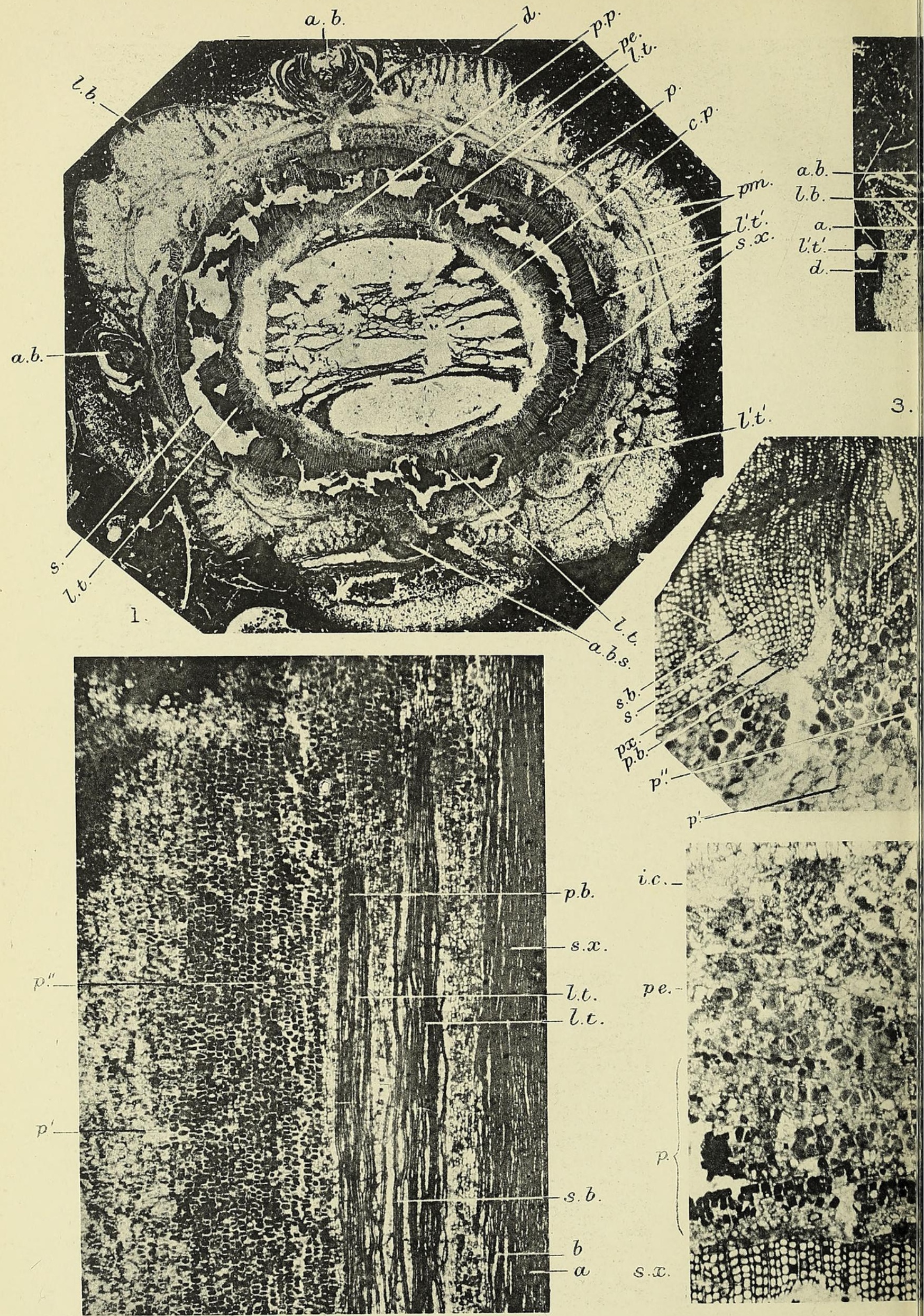



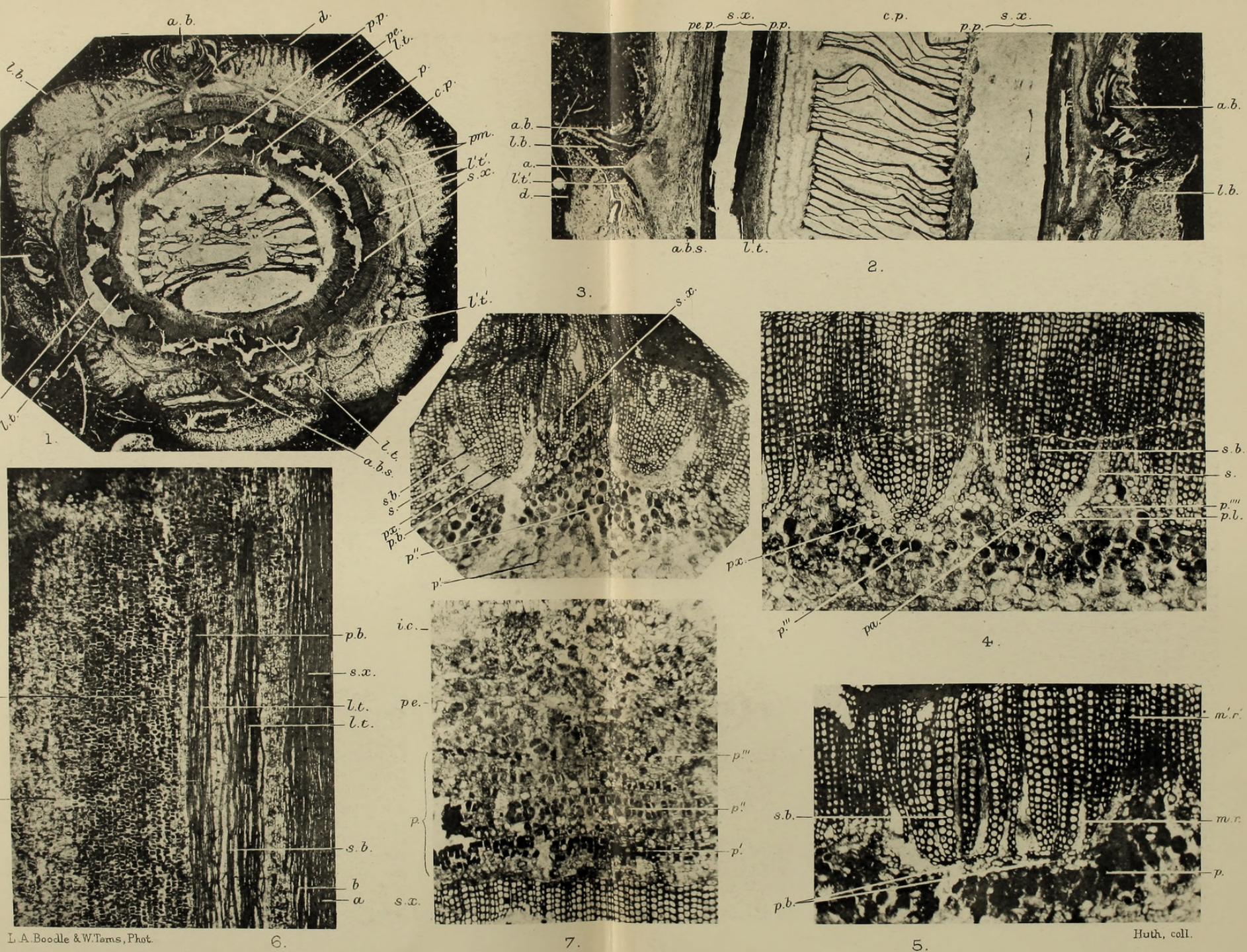


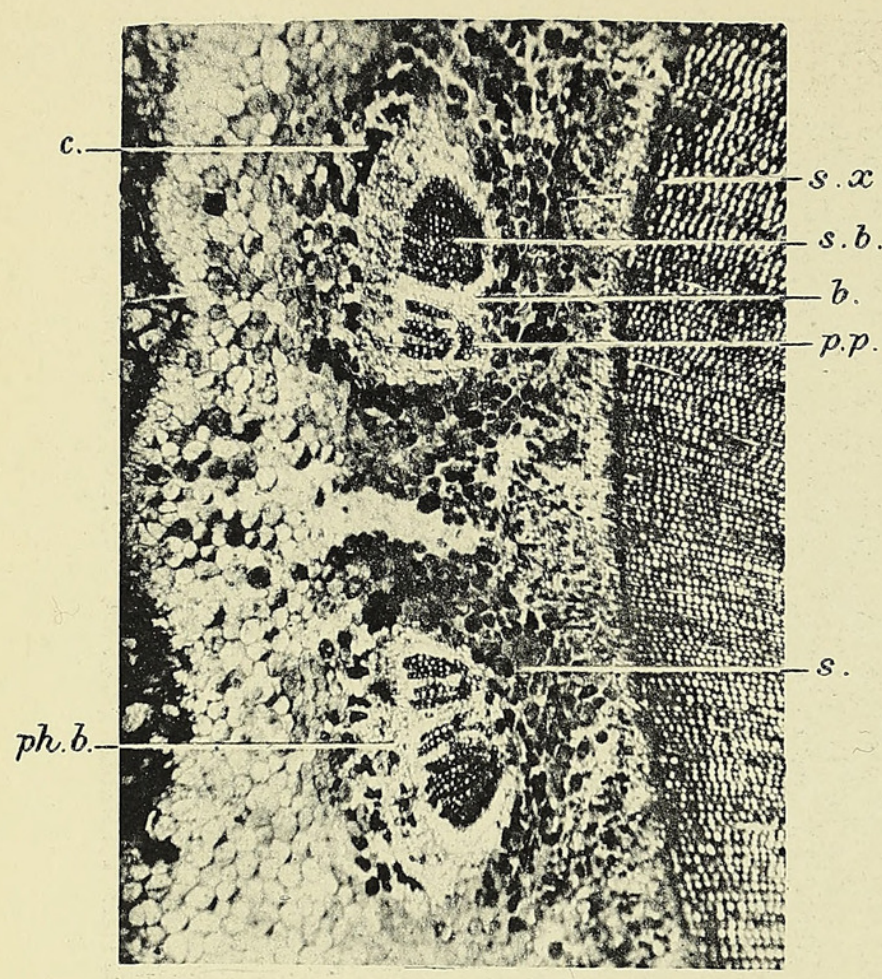

8.

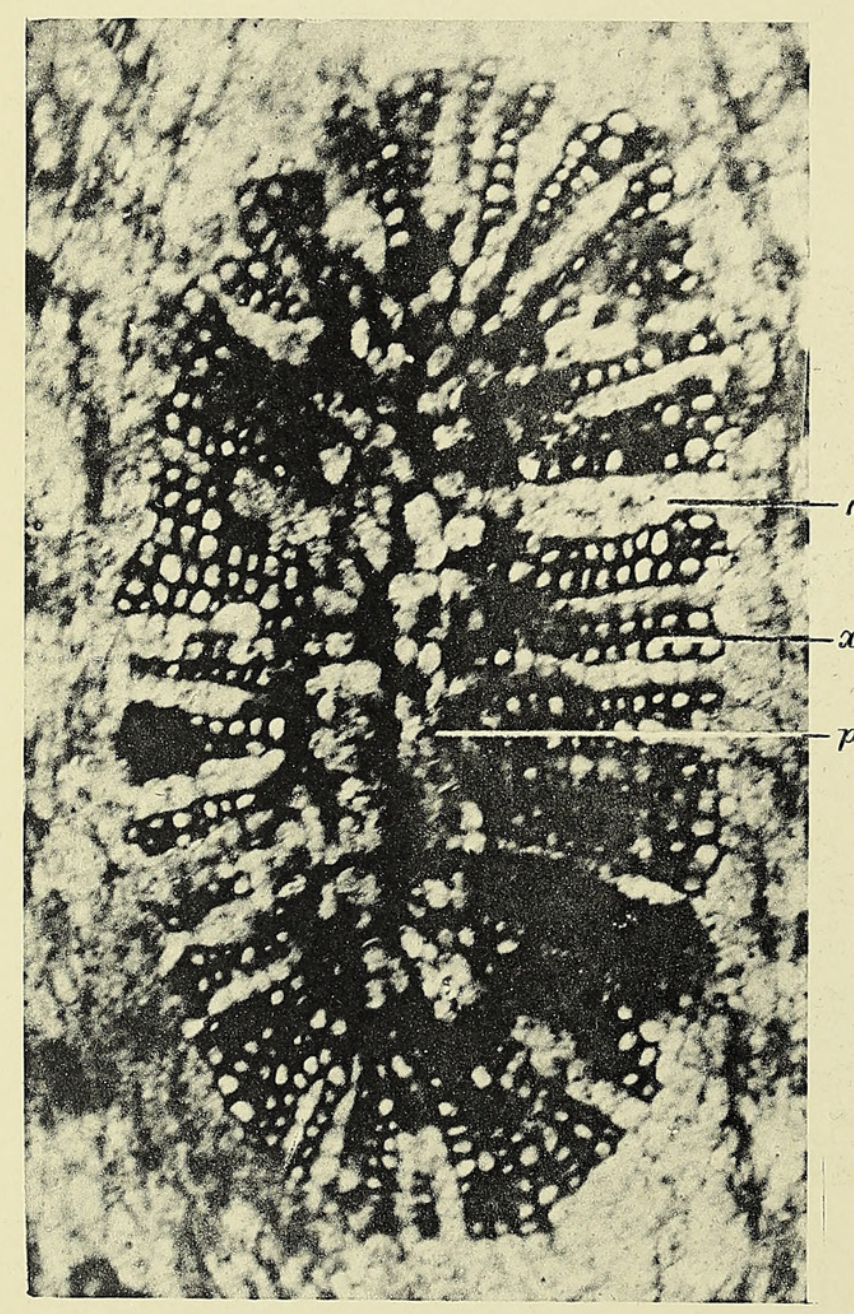

I. A. Boodle \& WTTams, Photo.

11.

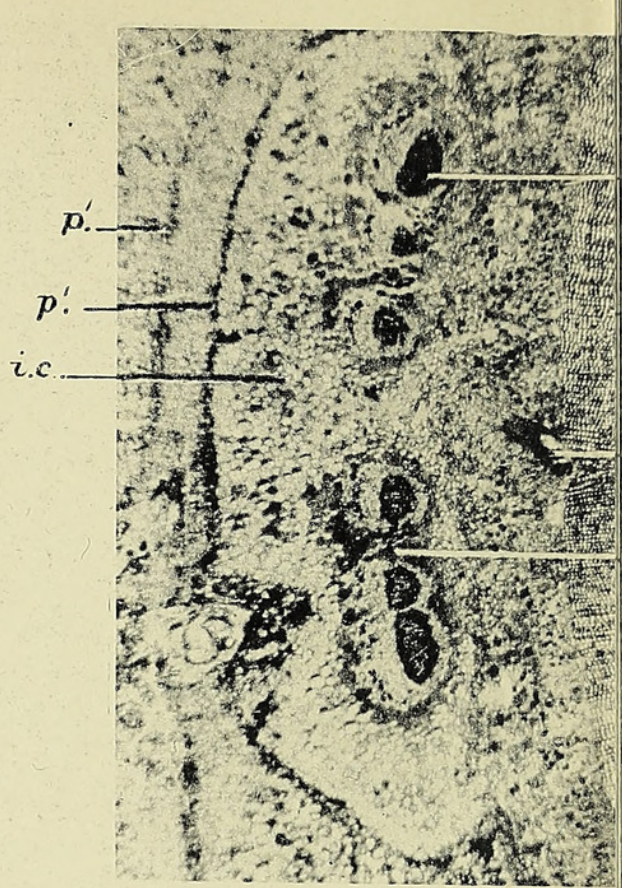

9

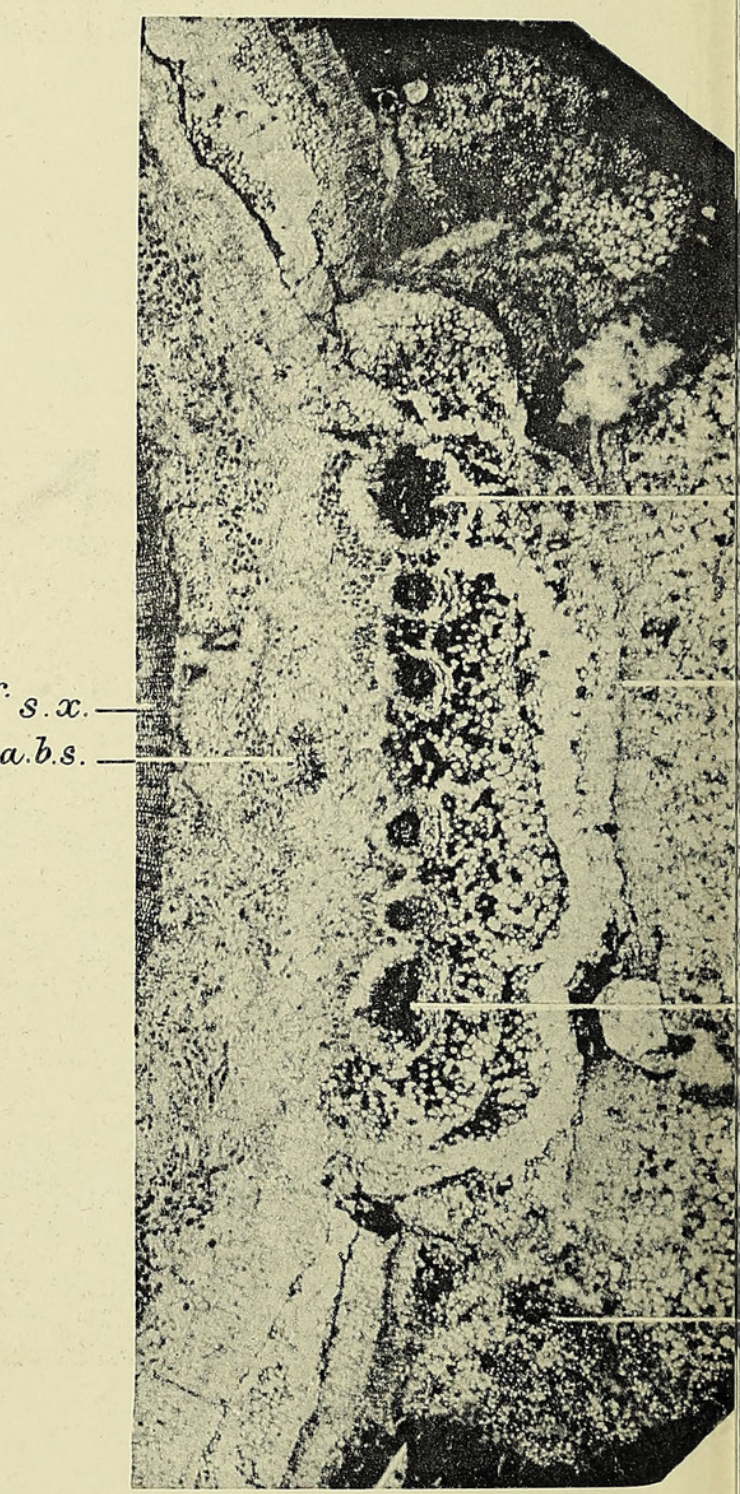

10. 


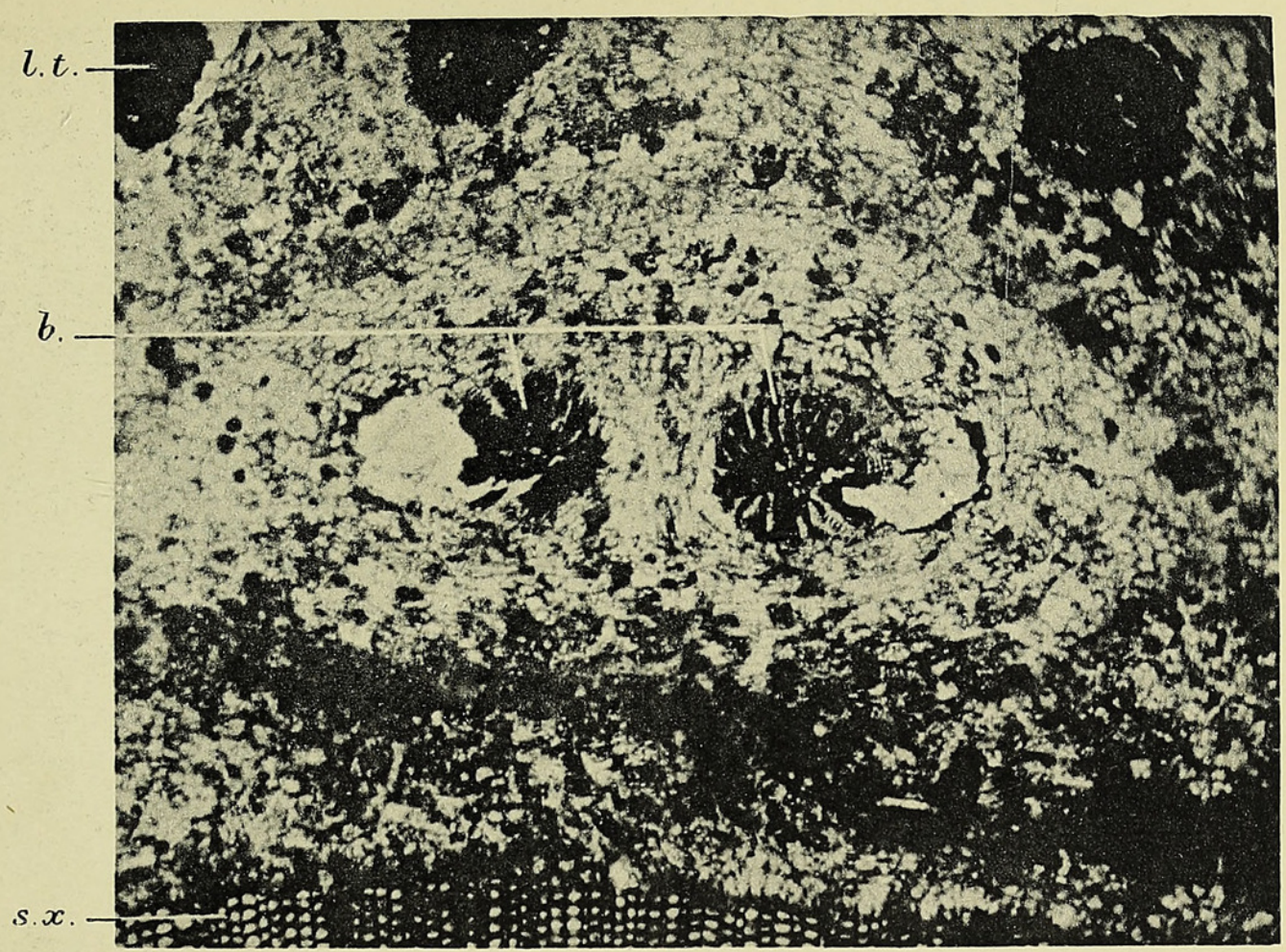

12.

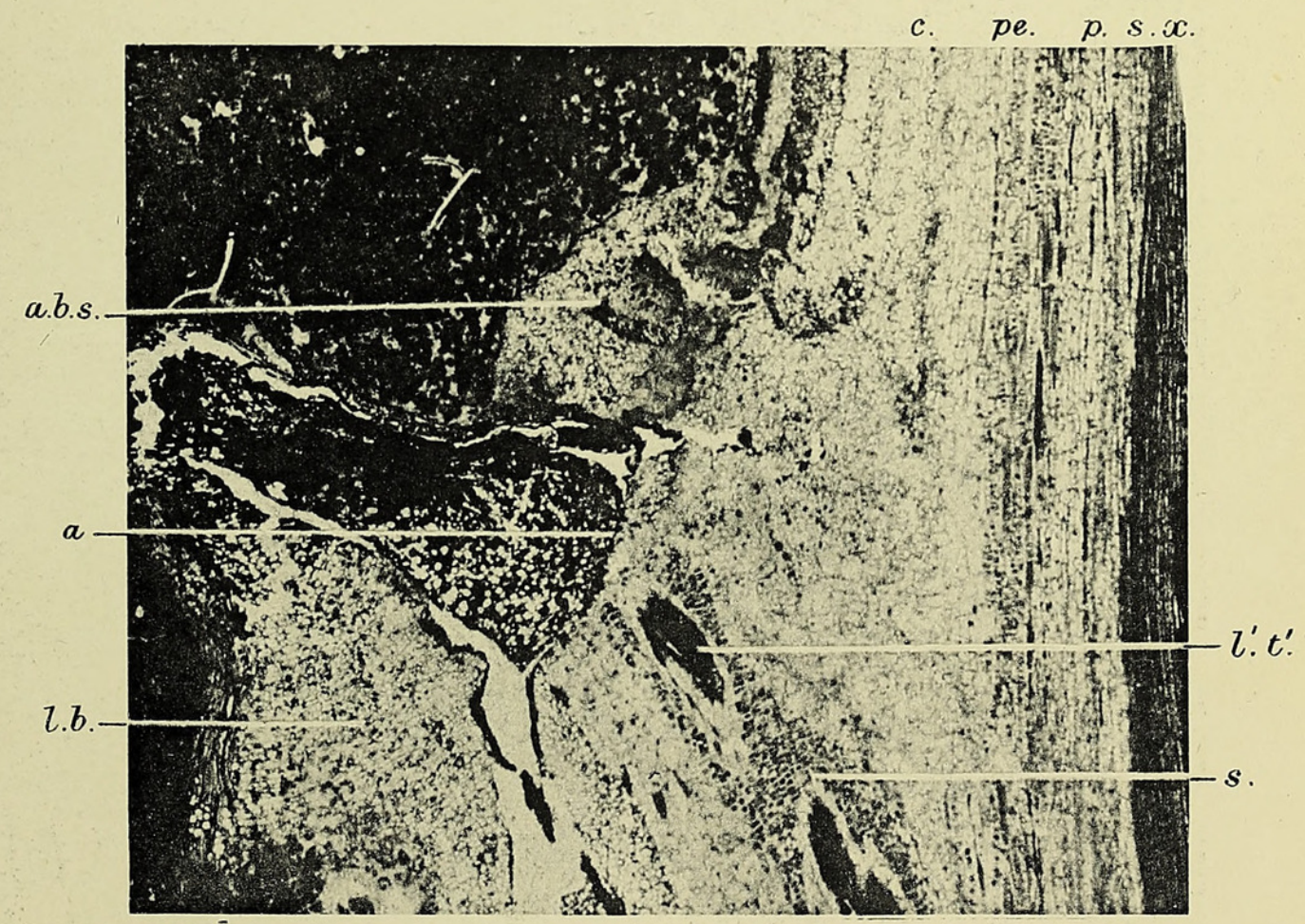




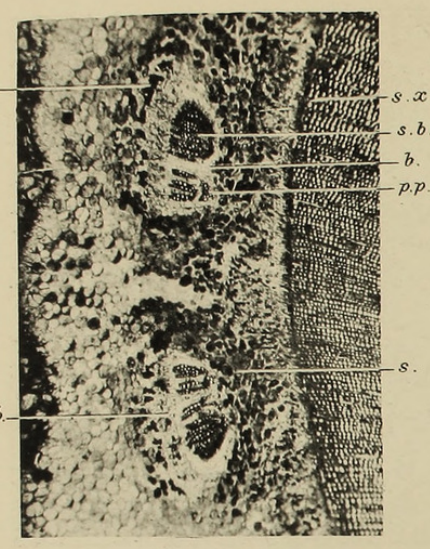

8.

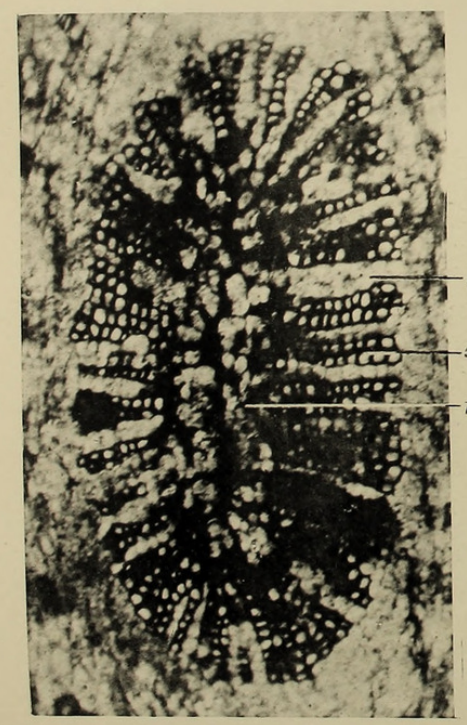

L.A. Boodle \& WTams, Photo. 11 .
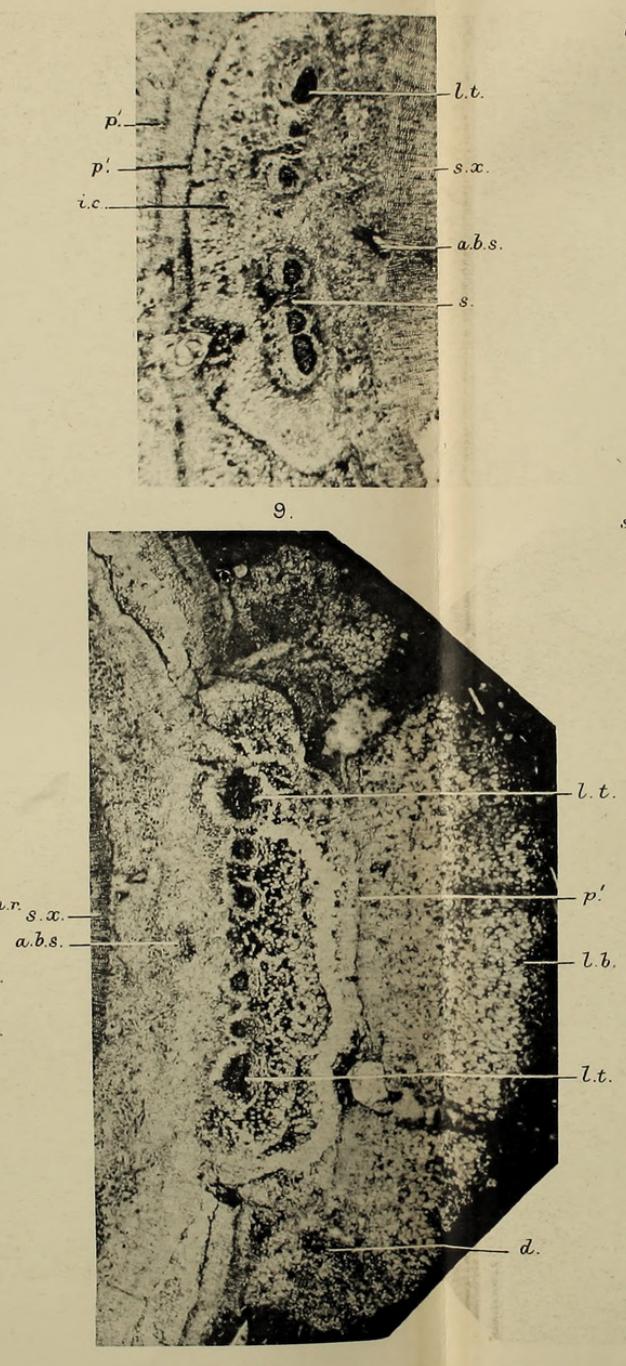

10.

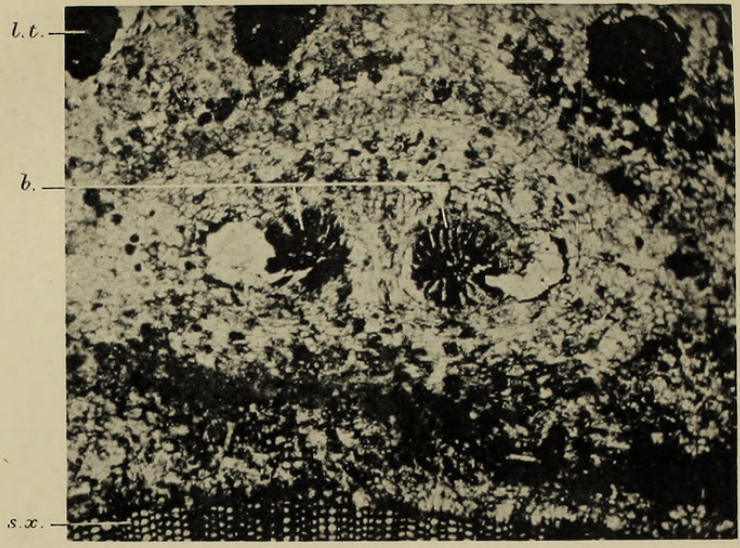

12

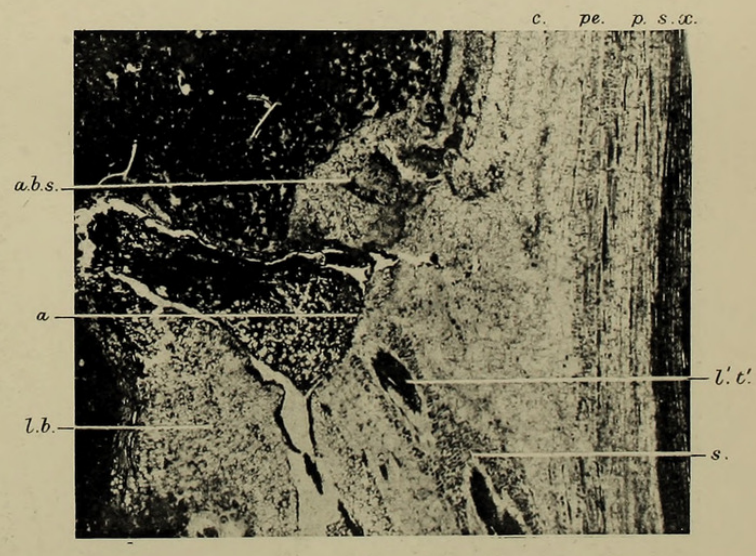

Huth, coll

MASLEN MESOXYLON SUTCLIFFII 


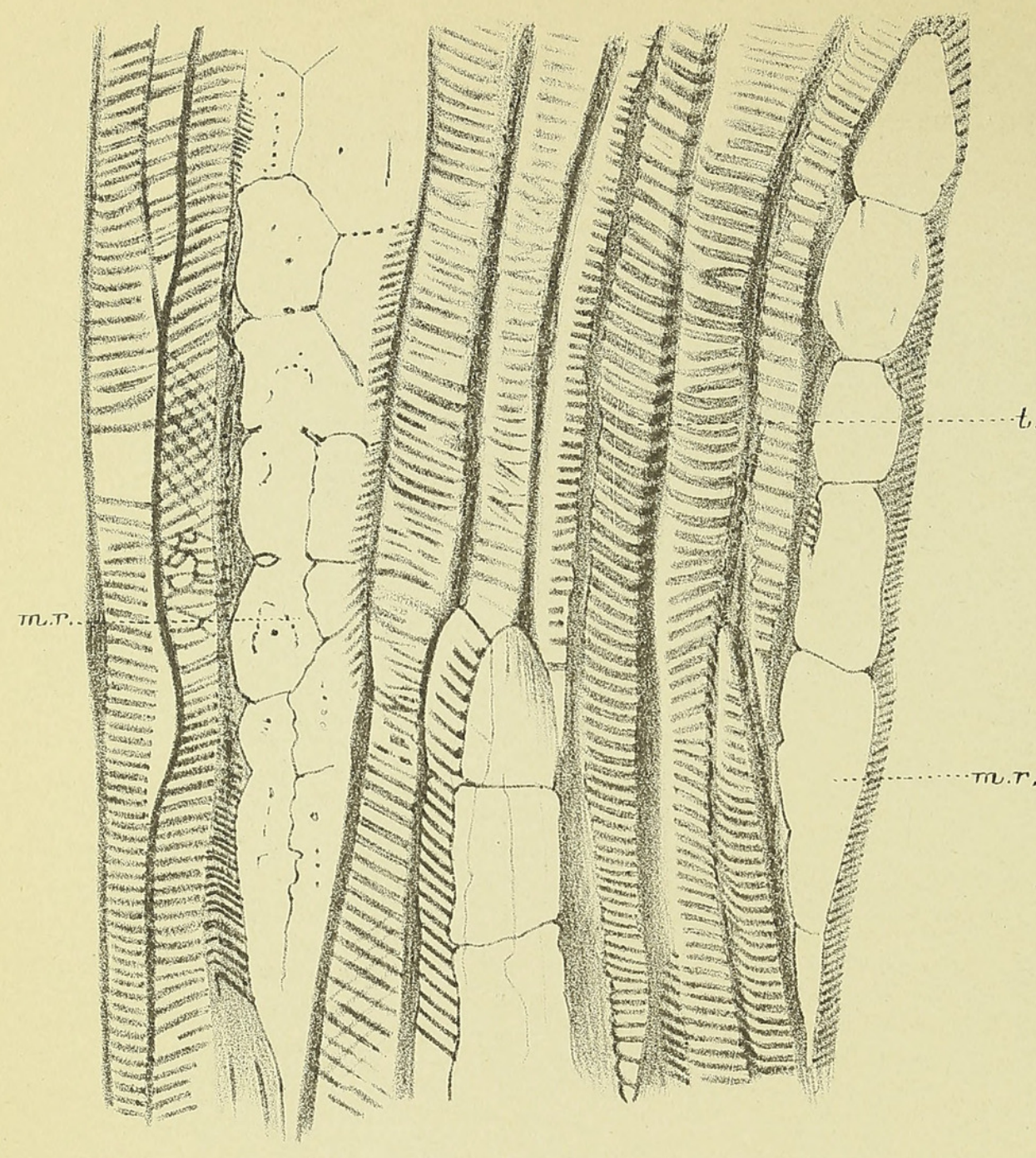

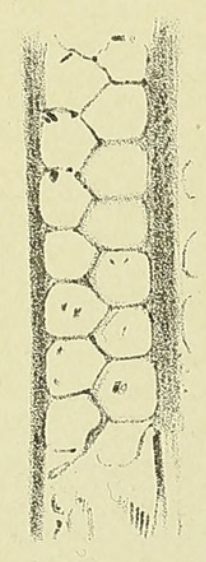

15.

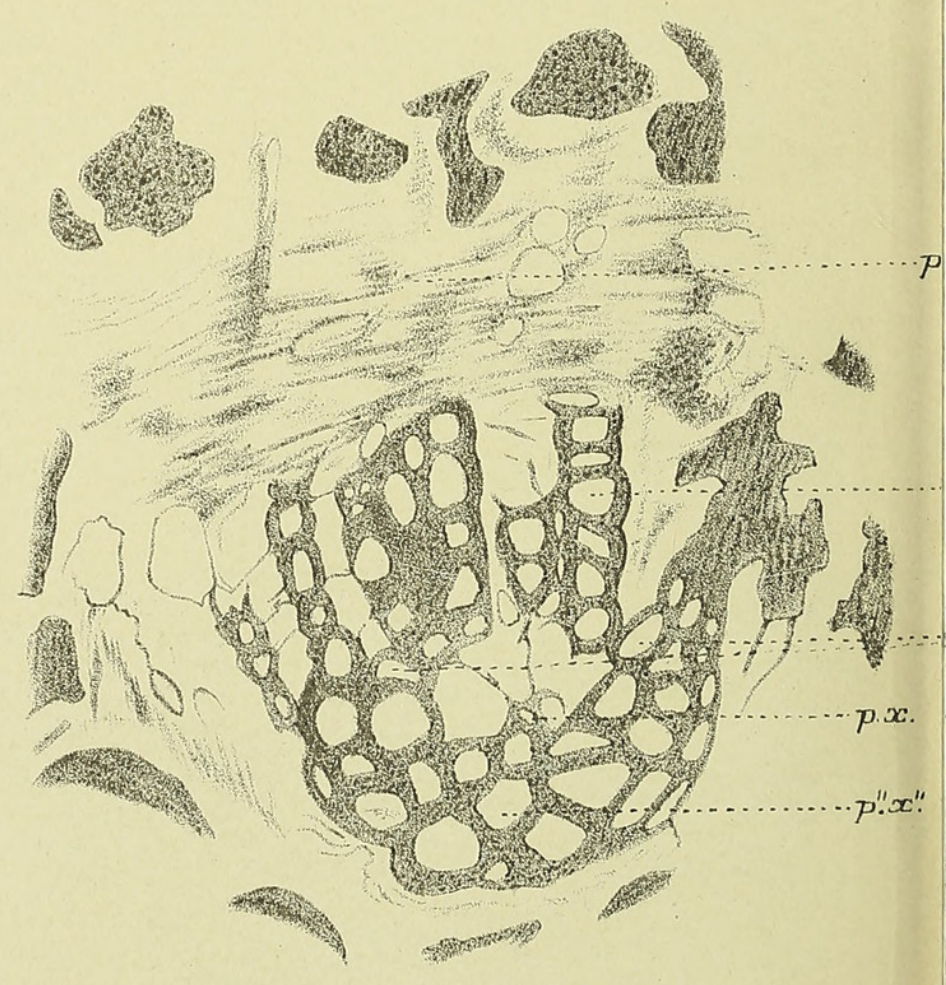

19. 


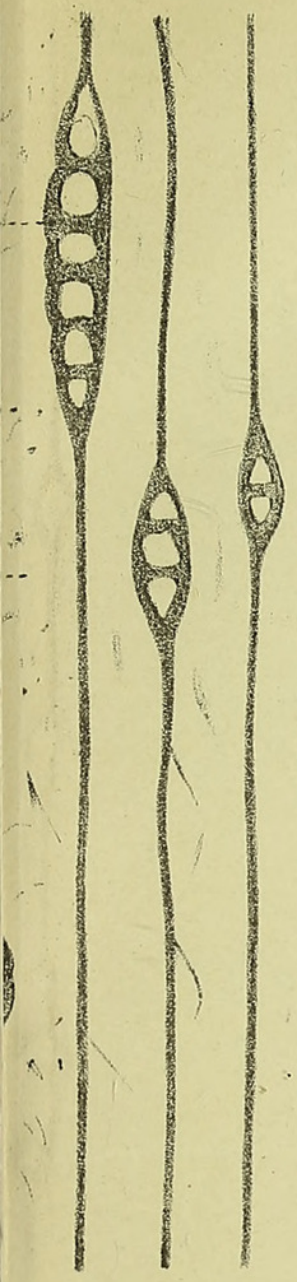

16

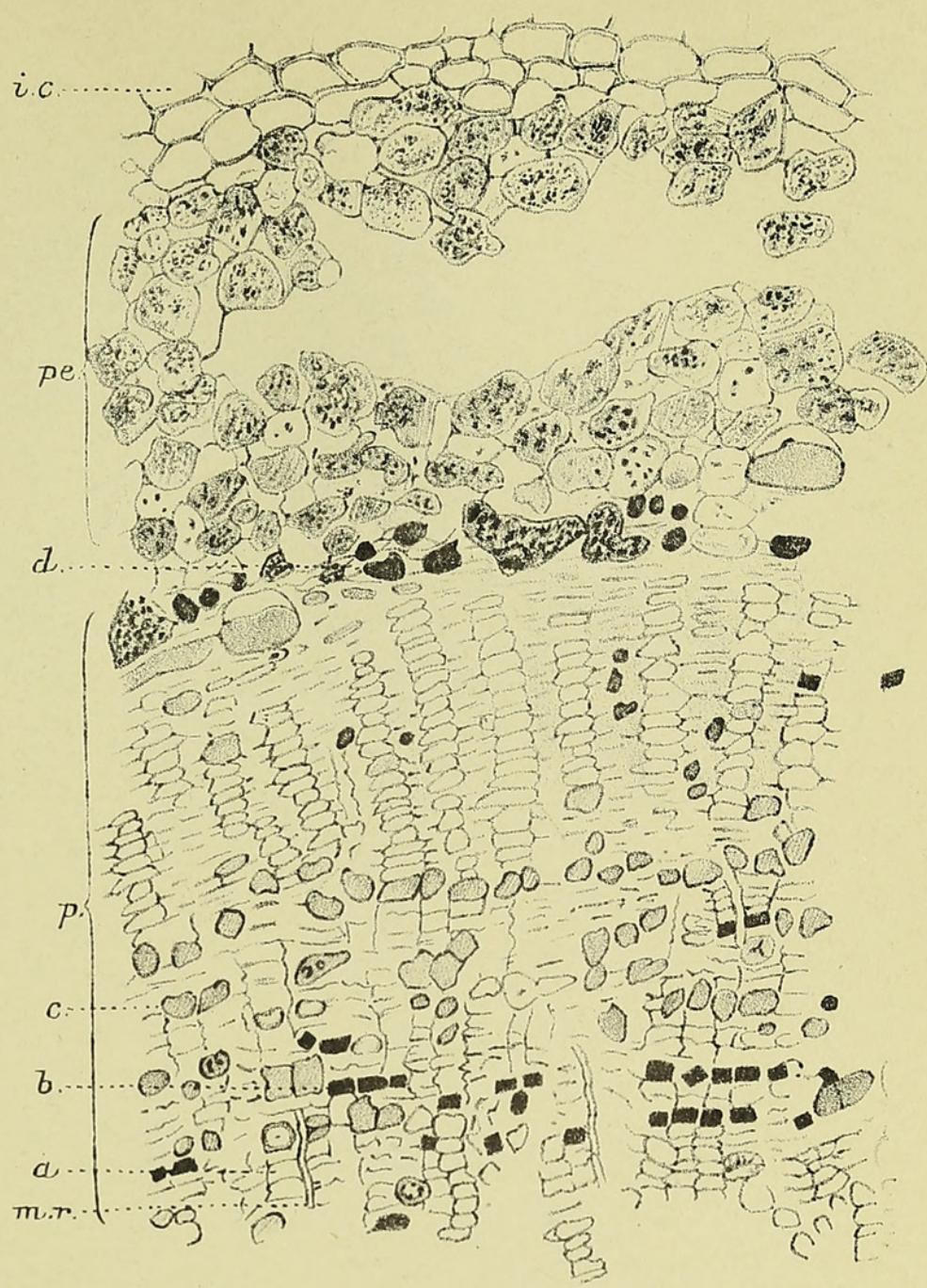

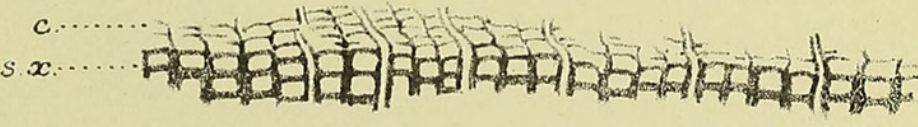

17.

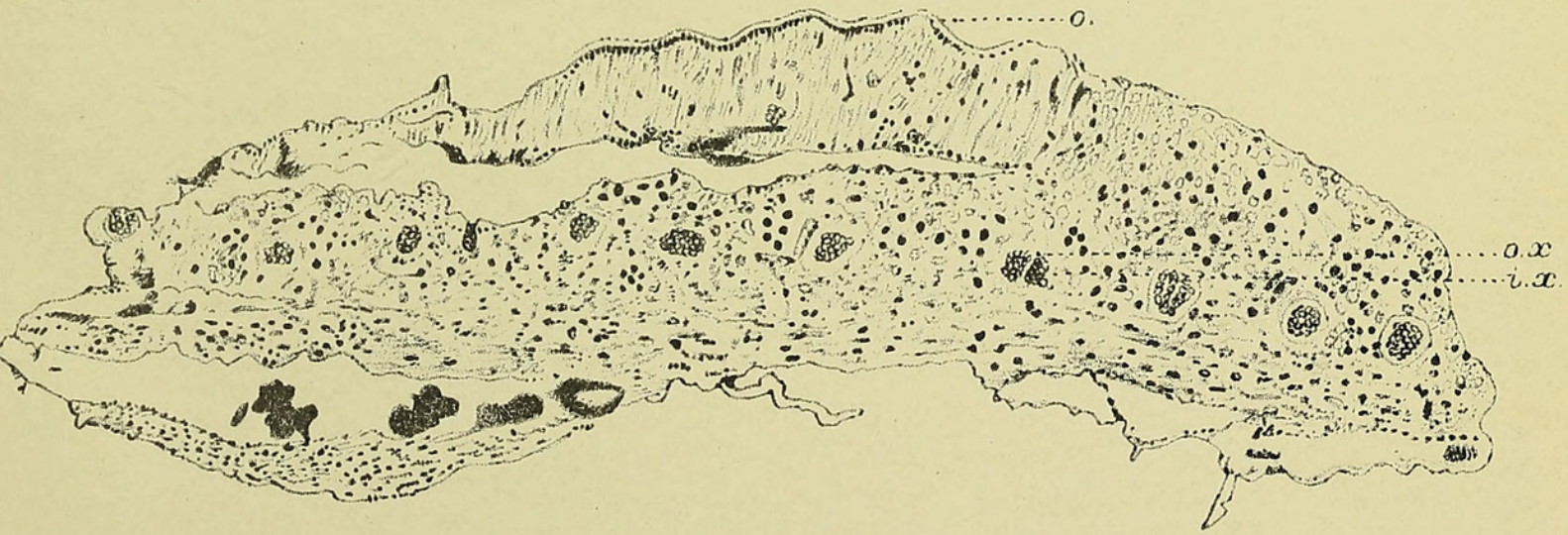

18. 

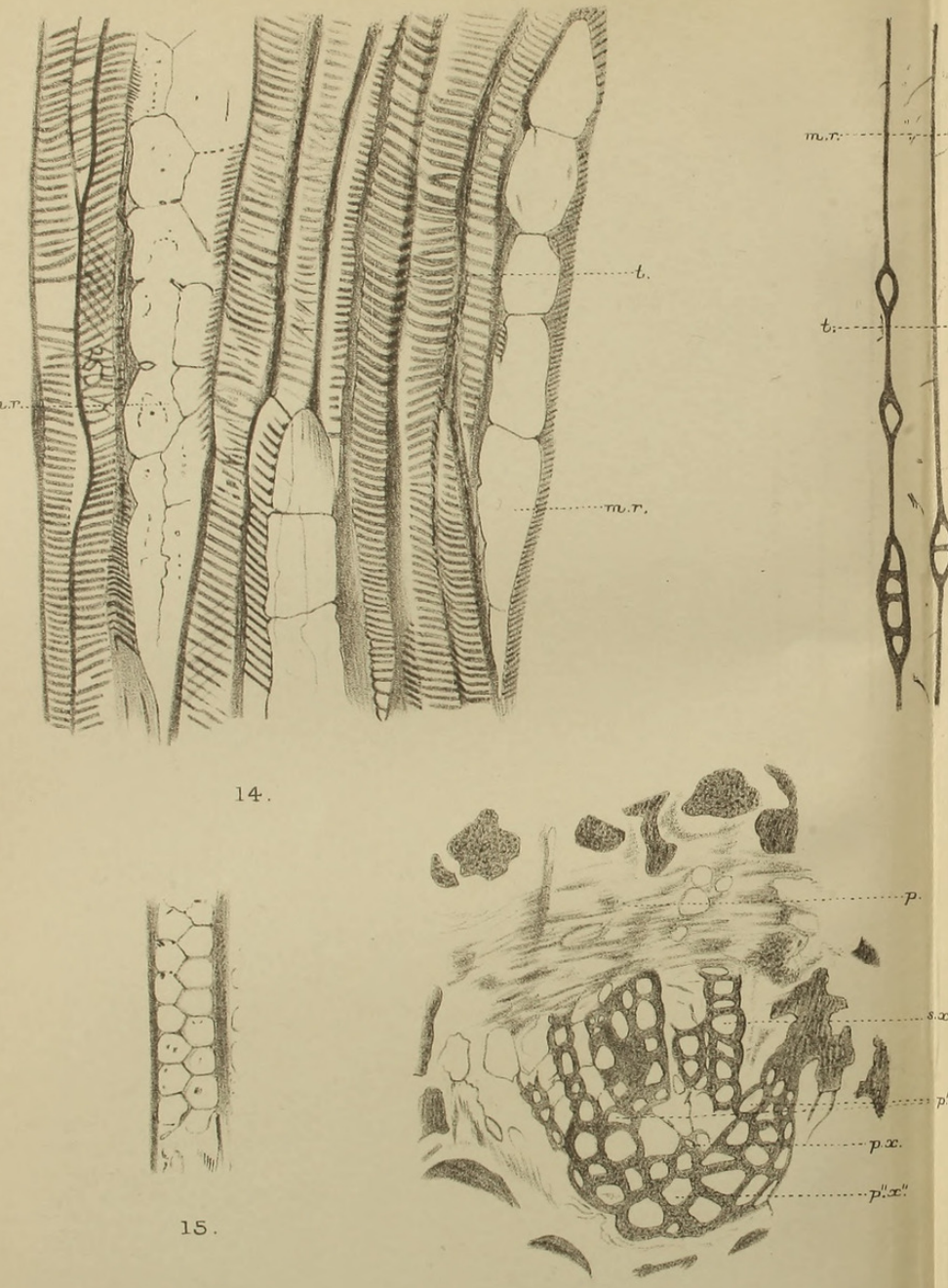

19.

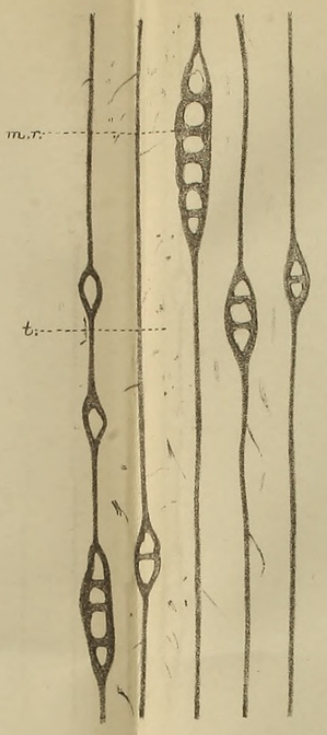

16.

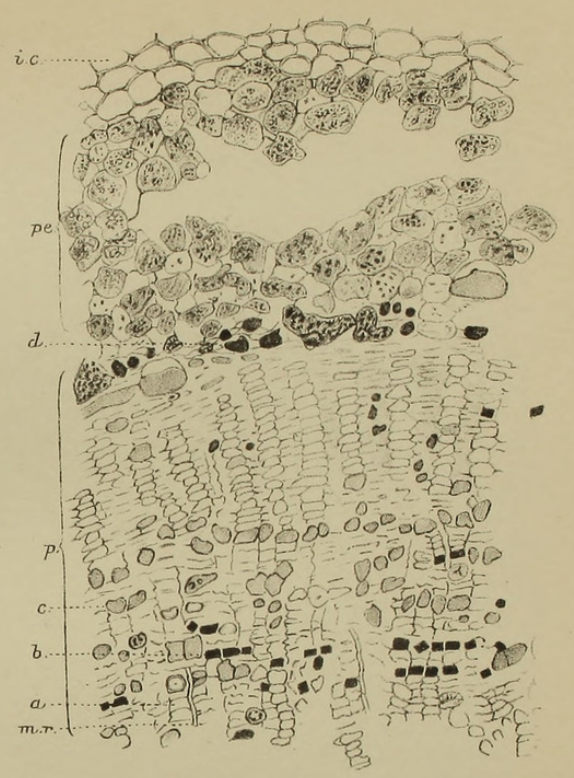

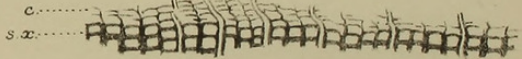

17.

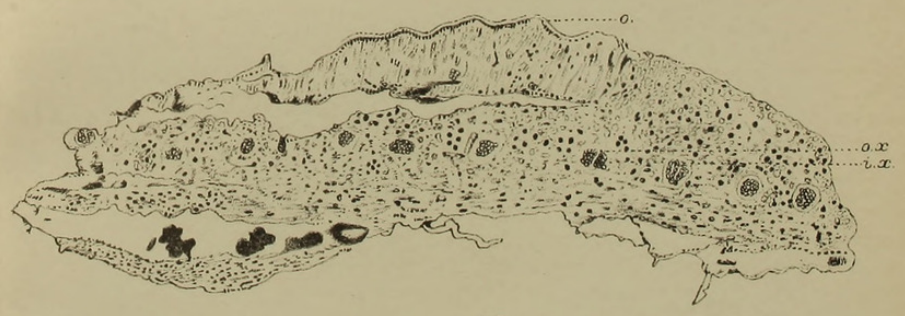

18. 
Annals of Botany,
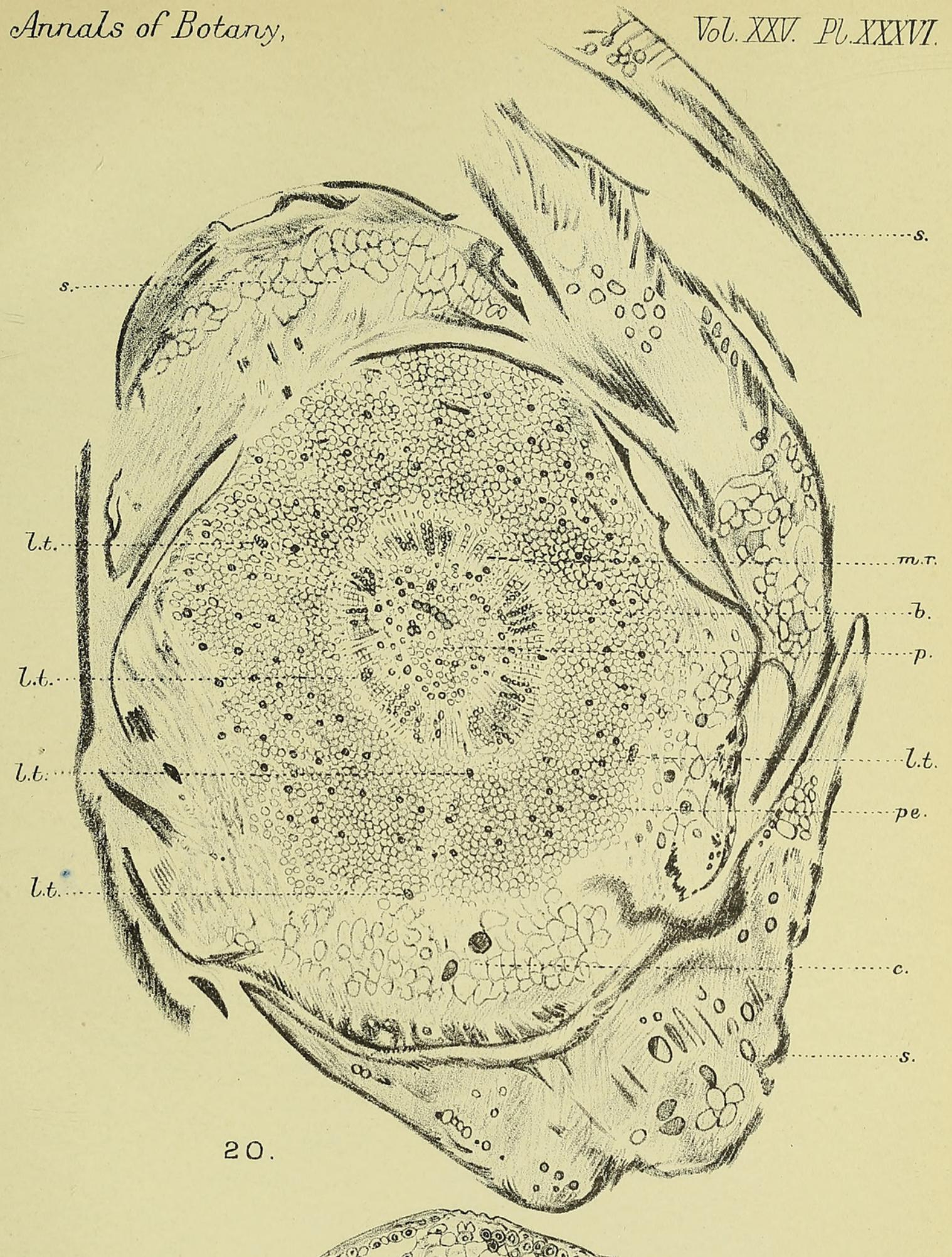

$10 \%$ r 


\section{$2 \mathrm{BHL}$ Biodiversity Heritage Library}

Maslen, Arthur J. 1911. "The structure of Mesoxylon sutcliffii (Scott)." Annals of botany 25, 381-414. https://doi.org/10.1093/oxfordjournals.aob.a089334.

View This Item Online: https://www.biodiversitylibrary.org/item/236971

DOI: https://doi.org/10.1093/oxfordjournals.aob.a089334

Permalink: https://www.biodiversitylibrary.org/partpdf/319842

\section{Holding Institution}

Smithsonian Libraries

\section{Sponsored by}

Biodiversity Heritage Library

\section{Copyright \& Reuse}

Copyright Status: Not in copyright. The BHL knows of no copyright restrictions on this item.

This document was created from content at the Biodiversity Heritage Library, the world's largest open access digital library for biodiversity literature and archives. Visit BHL at https://www.biodiversitylibrary.org. 